\title{
Disabilityqueer: Federal Disability Rights Protection for Transgender People
}

\author{
Kevin M. Barry*
}

The Americans with Disabilities Act (ADA) does not protect everyone. It notably excludes people with Gender Identity Disorder (GID), an impairment involving the misalignment between one's anatomy and gender identity. Many would say this is as it should be-gender nonconforming people are not impaired and so they should not be covered by disability law. But this argument misapprehends the reason that GID was excluded from the ADA in the first place.

GID was excluded from the ADA because, in 1989, a small handful of senators believed that gender nonconformity - like pedophilia, pyromania, and kleptomania-was morally harmful to the community. In the eleventh hour of a marathon floor debate, and in the absence of an organized transgender lobby, the ADA's sponsors and disability rights advocates reluctantly agreed to sacrifice GID and nine other mental impairments in exchange for passage in the Senate. The fact that Congress went out of its way to exclude GID, along with nine mental impairments that involve some harm to oneself or others, sends a strong symbolic message: people with GID have no civil rights worthy of respect. The ADA is a moral code, and people with GID its moral castaways.

In 2008, when Congress decided to expand the ADA's definition of "disability" to protect more people, things should have been different for people with GID. Sadly, they were not. Instead of removing the GID exclusion once and for all, Congress enshrined its moral opposition to people with

- Associate Professor, Quinnipiac University School of Law. This text is adapted from remarks originally delivered at a symposium sponsored by the Yale Human Rights \& Development Law Journal, entitled, "States, Minds, and States of Mind: Mental Health as a Human Right." Thanks to the following people for thoughtful comments on earlier drafts: E. Pierce Blue, Jennifer Brown, Ruth Colker, Chai Feldblum, Marcy Karin, Jennifer Levi, and Linda Meyer. Thanks also to participants at the Seventh Annual Labor and Employment Law Colloquium and Quinnipiac University School of Law's Faculty Forum for helpful conversations; to Sarah Grusin and Yale Human Rights E Development Law Journal staff for editorial assistance; and to Madison Barry, Tina DeLucia, Andrea Dupre, and Christine Gertsch for research assistance. 
GID by preserving the exclusion. The ADA's message to people with $G I D$, and to the transgender community more broadly, is now clearer than ever: nearly twenty years after the passage of the ADA, people with GID are still despicable and even dangerous, and therefore undeserving of legal protection. The ADA's moral code remains.

In order to achieve true equality, transgender advocacy must rebut the moral case against transgender people. The ADA should play a prominent role in this project because the ADA's GID exclusion is the moral case against transgender people. The ADA should be righted once more through passage of a modest bill, the "ADA Inclusion Act," which removes GID from the ADA's list of excluded impairments.

\section{INTRODUCTION}

Rachel Maddow. Jerry Sandusky. Chaz Bono. Although the ADA Amendments Act of 2008 (ADAAA) expanded the ADA's definition of disability to include medical impairments that are not typically thought of as "disabling," 1 it left intact the exclusion of those who are gay, lesbian, or bisexual, those with pedophilia and other sexual disorders, and those who are transgender. ${ }^{2}$ Many will say that this is as it should be.

Being gay, lesbian, or bisexual, after all, is not a medical impairment. In 1974, the American Psychiatric Association removed same-sex orientation from its standard classification of mental disorders, known as the Diagnostic and Statistical Manual (DSM). ${ }^{3}$ Because same-sex orientation is not an

1. Kevin Barry, Toward Universalism: What the ADA Amendments Act of 2008 Can and Can't Do for Disability Rights, 31 BERKELEY J. EMP. \& LAB. L. 203, 208 (2010) [hereinafter Barry, Toward Universalism] (discussing the ADA Amendments Act's protection of "nearly everyone from discrimination based on impairments" under the third prong and the relaxation of the "substantial limitation" requirement under the first and second prongs).

2. 42 U.S.C. $\$ 12211$ (2006). "Transgender" is an umbrella term that refers to those who are gender nonconforming. See Paisley Currah et al., Introduction, in TRANSGENDER RIGHTS xiv (2006). Generally speaking, it includes those diagnosed with Gender Identity Disorder (GID), as well as those without the diagnosis "whose gender identity or expression does not conform to the social expectations for their assigned sex at birth." $I d$.

3. Herb Kutchins \& Stuart A. Kirk, Making Us Crazy: DSM: The PSYChiatric Bible AND THE CREATION OF MENTAL DisORders 71-72 (1997). See generally About DSM-5, AM. PSYCHIATRIC ASS'N DSM-5 DEV. http://www.dsm5.org/about/pages/default.aspx (last visited Nov. 7, 2012) ("[DSM]" is the standard classification of mental disorders used by mental health professionals in the United States and contains a listing of diagnostic criteria for every psychiatric disorder recognized by the U.S. healthcare system."). Although the DSM "was developed for clinical, public health, and research purposes" - not legal ones - it nevertheless "has been recognized as an important reference by courts" and, according to the EEOC, "is relevant for identifying [mental] disorders." Proposed Revision, Definition of a Mental Disorder, AM. PSYCHIATRIC ASS'N DSM-5 DEv. Proposed revisions are no longer available online, but are on file with the author. Please see dsm5.org for the final version of the rule. [hereinafter Mental Disorder, DSM-5 Proposed Revision]; What is a "mental impairment" under the ADA?, EEOC, Notice No. 915.002, ENFORCEMENT GUIDANCE: THE AMERICANS WITH DISABILITIES ACT AND 
impairment, the argument goes, it should not be covered by the ADA. Rachel Maddow, for example, who is openly lesbian and the host of MSNBC's primetime news show, "The Rachel Maddow Show,"4 is excluded from the ADA's definition of disability because she has no medical impairment. The ADA should no more protect her, one might reasonably argue, than it should protect people with brown eyes, short legs, or dark hair. ${ }^{5}$ These are characteristics, not impairments, and therefore not the stuff of disability protection.

By contrast, pedophilia, the sexual attraction to prepubescent children, remains an impairment under the DSM and few would argue that it should not be. ${ }^{6}$ But disability coverage for pedophiles is another matter; one might reasonably argue that the ADA should not extend to pedophiles because they threaten the safety of one of our most precious resources-our future.? Jerry Sandusky, for example, who is the former defensive coordinator for the Penn State football team and was arrested in 2011 for sexually abusing eight boys over a 15 -year period, ${ }^{8}$ has a medical impairment alright. He, too, is excluded from the ADA's definition of disability, but for a very different reason than Rachel Maddow. He is excluded because he is morally depraved and therefore undeserving of disability protection. ${ }^{9}$

PSYCHIATRIC DISABILITIES (1997) available at http://www.eeoc.gov/policy/docs/psych.html.

4. Jessica Pressler, The Dr. Maddow Show, N.Y. MAG. Nov. 2, 2008, http://nymag.com/ news/media/51822/.

5. 29 C.F.R. Pt. 1630, App. (2010) ("The definition of the term 'impairment' does not include physical characteristics such as eye color, hair color, left-handedness, or height, weight, or muscle tone that are within "normal' range and are not the result of a physiological disorder.").

6. Pedophilic Disorder: Proposed Revision, AM. PSYCHIATRIC Ass'N DSM-5 DEV. Proposed revisions are no longer available online, but are on file with the author. Please see dsm5.org for the final version of the rule.

7. This is not to say that reasonable arguments cannot also be made for disability coverage of pedophiles. See infra note 189 .

8. Mark Viera, Former Coach at Penn State Is Charged With Abuse, N. Y. TIMES (Nov. 5, 2011), http://www.nytimes.com/2011/11/06/sports/ncaafootball/former-coach-at-penn-state-ischarged-with-abuse.html.

9. One might reasonably argue that gay, lesbian, and bisexual people were excluded from the ADA not because legislators believed they were not impaired, but rather because legislators believed that they, too, were morally suspect. Much of the ADA's legislative history, including the original ADA bill passed by the Senate, supports this argument. See Ruth Colker, Homophobia, AIDS Hysteria, and the Americans with Disabilities Act, 8 J. GENDER RACE \& JUST. 33, 44-46, 49-50 (2004) [hereinafter Homophobia] (discussing ADA's legislative history). Nevertheless, because the final version of the ADA clarified that "homosexuality and bisexuality are not impairments and as such are not disabilities," the text of the law supports a clear distinction in the reasoning for excluding homosexuality and bisexuality, on the one hand, and a host of other conditions, on the other. 42 U.S.C. $\$ 12211$ (2005). See also infra notes 130-31 and accompanying text. Cf. Katrina C. Rose, Where the Rubber Left the Road: The Use and Misuse of History in the Quest for The Federal Employment Non-Discrimination Act, 18 TEMPLE POL'L \& CIV'L RTS. L. REV. 397, 436 n.199 (2009) (quoting Steve Smith, a lobbyist for the Human Rights Campaign Fund at time of the ADA's passage, who praised the ADA exclusions; and Peri Jude Radecic, who agreed with the ADA's exclusion of homosexuality and bisexuality but noted that "as far as the other categories are concerned, I think that anytime that people are removed from protections, I don't necessarily think that's a good situation. I'm not happy anyone is excluded from 
Gender Identity Disorder (GID), which involves the misalignment between one's anatomy and gender identity, is a harder case. ${ }^{10}$ According to proposed changes to the DSM, which will take effect in 2013, people with GID experience, or are at risk of experiencing, distress if they do not receive the right support, ranging from talk therapy to pharmacological and surgical interventions. ${ }^{11}$ The fact that GID remains a listed DSM diagnosis, coupled with the fact that having GID has nothing to do with hurting people, ${ }^{12}$ would appear to favor disability coverage under the ADA. But some in the transgender community-echoing the call of gay, lesbian, and bisexual people over thirty years ago-believe that GID is not a mental impairment and therefore has no business being in the DSM. ${ }^{13}$ Accordingly, one might argue, GID has no business being in the ADA either. GID sits at the uneasy crossroads of pathology and difference.

While reasonable arguments can be made for the exclusion of GID under the ADA, the ADA's current exclusion of GID is not a reasonable one. ${ }^{14}$ GID is explicitly excluded from the ADA not because people with GID are not impaired (Rachel Maddow), but rather because, in 1989, several members of Congress believed that people with GID were morally bankrupt, dangerous, and sick (Jerry Sandusky). The ADA became a moral code separating the deserving disabled from the subjects of scorn, with people with GID falling squarely into the latter camp. Chaz Bono, for example, a transgender man, and the child of Sonny Bono and Cher, who danced his way into American's living rooms two years ago, is not protected by the ADA. ${ }^{15}$ Whether or not one believes that Chaz Bono has an impairment is beside the point - the ADA says that he does have an impairment, but that

the bill"). Peri Jude Radecic was a lobbyist for the National Gay and Lesbian Task Force at the time of the ADA's passage. See Peri Jude Radecic Takes Over as Executive Director of the Arizona Center for Disability Law, ARIZONA CENTER FOR DISABILITY LAW, (May 29, 2007), http://www.acdl.com/PR052907.htm.

10. See Gender Dysphoria in Adolescents or Adults: Proposed Revision, AM. PSYCHIATRIC Ass' N DSM-5 DEV. Proposed revisions are no longer available online, but are on file with the author. Please see dsm5.org for the final version of the rule [hereinafter Gender Dysphoria, DSM-5 Proposed Revision].

11. Id.

12. Not everyone would agree with this statement. Those in an intimate relationship with someone who "comes out" as transgender might say otherwise. But as physically mature, consenting adults, their hurt is different in kind from that of a prepubescent child.

13. See Judith Butler, Undiagnosing Gender, in TRANSGENDER RIGHTS, supra note 2, at 274.

14. See L. Camille Hébert, Transforming Transsexual and Transgender Rights, 15 WM. \& MARY J. WOMEN \& L. 535, 540-41 (2009) ("While one might argue for the exclusion of certain conditions from the definition of disability as justified by not wanting to pathologize certain individuals and conditions, this does not appear to have been the motivation of Congress.") (citation omitted).

15. Chaz Bono was a cast member of ABC's "Dancing with the Stars" in 2011. Elizabeth Flock, Chaz Bono on 'Dancing With the Stars' puts Transgender Rights in Spotlight, WASH. POST (Sep. 1, 2011), http://www.washingtonpost.com/blogs/blogpost/post/chaz-bono-ondancing-with-the-stars-puts-transgender-rights-inspotlight/2011/09/01/gIQAIMj2uJ_blog.html. 
he, like Jerry Sandusky, is not morally deserving of protection.

The ADAAA could have changed things for people with GID, but it did not do so. In fact, by changing nearly everything about the definition of disability except the ADA's list of exclusions, the ADAAA appears to ratify the ADA's moral disapprobation of people with GID. Law can sometimes create the very thing it seeks to dismantle, and the ADA is a case in point.

By expanding the definition of disability, the ADAAA signaled that nearly everyone, not just those traditionally considered "disabled," should be protected from discrimination based on impairment. The newly amended ADA's scope of coverage is nearly universal. Accordingly, the ADA does not protect "those" people with stigmatized impairments that impose severe functional limitations; it now protects all of us who are treated unfairly based on impairment, whether or not our impairments are typically thought of as disabilities. Like the "Genderqueer" who blur the boundaries between gender's perceived poles of male and female, the newly amended ADA is "disabilityqueer," blurring the line between the nondisabled and the disabled - between the healthy "us" and the unfortunate "them." 16

But by maintaining the GID exclusion, the ADAAA cemented GID's last-place position in the hierarchy of mental impairments. Now more than ever, the ADA "disables" people with GID.

While the ADAAA's preservation of GID's place in the hierarchy of im-

16. The newly amended ADA is disabilityqueer in the sense that its expanded definition of "disability" protects almost any one of us who is treated adversely based on an impairmenteven those whose impairments are not typically thought of as disabling. See infra notes 160-67. For example, under the amended ADA, a person with controlled asthma, epilepsy, diabetes, or anxiety, who is refused an accommodation, or a person fired because of a bad back, ankle injury, carpal tunnel syndrome, or high-functioning autism, is "disabled." By the same token, those who comprise this vastly expanded group of people now considered "disabled" under the ADA are, themselves, disabilityqueer; they are "disabled" in the eyes of the law but are not typically considered to be "disabled" by the rest of society. In this way, disabilityqueer refers to both the laws and the people who blur the boundaries between disabled and nondisabled.

"Disabilityqueer" is closely related to the concept of "bi-ability" articulated by Professor Ruth Colker. See Ruth Colker, Bi: Race, Sexual Orientation, Gender, and Disability, 56 OHIO ST. L.J. 1, 1 n.4 (1995). According to Professor Colker, "bi-ability" refers to those who are not covered by disability law but who nevertheless experience disadvantage based on their impairments, including those not typically considered to be disabled (e.g., a person with controlled asthma, epilepsy, or diabetes; an obese person who cannot fit into a movie theater seat; a child with "strabismus (commonly known as crossed eyes)" who lacks depth perception). Id. at 5859, 61-62. Such people are "neither disabled [under the law] nor able-bodied" - they are in between. Id. at 1 n.4. Under the pre-amendments ADA, there were many bi-abled. "Disabilityqueer," on the other hand, refers to those who are covered by disability law but are not typically considered to be disabled (e.g., people with carpal tunnel syndrome, ankle injuries, back injuries, high-functioning autism, and so on). By expanding the definition of disability under the ADA's first prong and covering nearly all people under the "regarded-as" prong, the 2008 amendments to the ADA reduce the number of bi-abled and increase the number of disabilityqueer. See also Elizabeth F. Emens, Disabling Attitudes: U.S. Disability Law and the ADA Amendments Act, 60 AM. J. COMP. L. 205, 223-25 \& n.92 (2012) (preferring term "bidisability" over "bi-ability," and discussing ADAAA's purported conversion of "many of the bidisabled into the legal category of disability"). 
pairments is understandable as a political matter, it is unfortunate. GID was originally excluded from the ADA for moral reasons: "transgender is bad." But times have changed. The transgender rights movement has found its voice. Transgender people have won significant legal battles at the federal, state, and local levels, including battles before the U.S. Equal Employment Opportunity Commission, which ruled in April 2012 that transgender discrimination is "sex" discrimination under Title VII. ${ }^{17}$ And Chaz Bono is dancing with the stars. At long last, transgender is becoming good. ${ }^{18}$

As one scholar recently put it, "[f]ederal law has an important expressive function, especially concerning the messages it sends about disadvantaged groups." 19 While protection of transgender people under existing federal and state "sex" discrimination laws and state "gender identity" discrimination laws is an essential part of making transgender "good," it does not erase the stain in federal disability law that likens people with GID to people who hurt others and burn and steal things. It does not eliminate the fact that federal disability law stigmatizes transgender people. Removing the ADA's intractable GID exclusion should be part of the project of making transgender good. The ADA's definition of disability should be righted once more.

This Article begins with a brief introduction to the ADA and its comprehensive prohibition of disability discrimination. Next, this Article discusses the ADA's legislative history and the untold back-door deal that resulted in the exclusion of GID. Here, my goal is to unmask, to expose why exactly the ADA protects all physical impairments but only some mental impairments - the ones we pity, not the ones we despise. ${ }^{20}$

I then turn the clock forward seventeen years to the negotiations that culminated in passage of the ADAAA. I discuss why the Amendments maintained the ADA's GID exclusion despite its broad expansion of the definition of disability, the emergence of a powerful transgender lobby, and growing support for transgender people in popular culture and under state and federal law. ${ }^{21}$

17. Macy, EEOC Appeal No. 0120120821, 2012 WL 1435995 (April 20, 2012).

18. This is not to say that transgender people do not still have a long way to go. See, e.g., JAIME M. GRANT ET AL., INJUSTICE AT EVERY TURN: A REPORT OF THE NATIONAL TRANSGENDER DISCRIMINATION SURVEY 2-8 (2011) available at $\mathrm{http}: / /$ www.thetaskforce.org/downloads/ reports/reports/ntds_full.pdf_[hereinafter "INJUSTICE AT EVERY TURN"] (documenting rampant discrimination against transgender people in education, employment, family life, public accommodations, housing, health care, jails, interactions with police, and obtaining ID documents); Shannon Price Minter, Do Transsexuals Dream of Gay Rights? Getting Real About Transgender Inclusion, in TRANSGENDER RIGHTS, supra note 2, at 146-50 (discussing reluctance of mainstream LGB movement to accept transgender people).

19. Michael Waterstone, Returning Veterans and Disability Law, 85 NOTRE DAME L. REv. 1081, 1122 (2010).

20. See infra Part II.

21. See infra Part III. 
This Article then looks to the future, and considers what, if anything, ought to be done about the ADA's exclusion of GID. After discussing some likely counter-arguments from the transgender community, this Article concludes that the ADA's definition of disability should be amended to provide federal disability rights protection for people with GID. ${ }^{22}$

\section{A COMPREHENSIVE CIVIL RIGHTS ACT}

In order to understand the ADA's past and present (and recommendations for its future), some brief background is in order. The ADA is a comprehensive civil rights law that prohibits discrimination based on disability in a range of areas, including private employment (Title I), governmental benefits and services (Title II), and places of public accommodation (Title III). ${ }^{23}$ In order for people to claim protection under the ADA, they must show that they have a "disability" as defined by the statute. ${ }^{24}$ Simply put, a person can show that he or she is disabled - and therefore protected under the ADA - if that person (1) actually has, (2) has a record of having, or (3) is regarded by others as having a "physical or mental impairment that substantially limits one or more major life activities." 25

Congress intended this definition to be interpreted broadly. The word "impairment," for example, is defined broadly under the ADA's regulations to include virtually any physiological or mental disorder. ${ }^{26}$ And the third prong of the definition of disability (the "regarded-as" prong), which covers those whose impairments are not substantially limiting and even non-existent, was intended to be a catch-all for those not covered under the first and second prongs. ${ }^{27}$

When compared with the definition of disability under the Social Security Act, the breadth of the ADA's intended scope of coverage becomes clear. The Social Security Act provides cash benefits to people who cannot work

22. See infra Part IV.

23. See Americans with Disabilities Act of 1990, 42 U.S.C. §§ 12111-17 (workplace); §§ 12131-65 (state and local government); $\$ \S 12181-89$ (public accommodations) (2006); see also Americans with Disabilities Act of 1990, Pub. L. No. 101-336 ("An Act To establish a clear and comprehensive prohibition of discrimination on the basis of disability.").

24. See id. at $\$ 12102(2)(\mathrm{A})-(\mathrm{C})$.

25. Id. at $\S 12102(2)(\mathrm{A})-(\mathrm{C})$ ); see also Kevin Barry, Exactly What Congress Intended?, 17 EMPLOYEE RTS. \& EMPLOYMENT POL'Y J. (forthcoming 2013) [hereinafter, Congress Intended].

26. See 29 C.F.R. $\$ 1630.2$ (h) (2012) ("Physical or mental impairment means - (1) [a]ny physiological disorder or condition, cosmetic disfigurement, or anatomical loss affecting one or more body systems..." or "(2) [a]ny mental or psychological disorder, such as mental retardation, organic brain syndrome, emotional or mental illness, and specific learning disabilities."); see also Samuel R. Bagenstos, Subordination, Stigma, and Disability, 86 VA. L. REV. 397, 407 (2000) (stating that "impairment" is "sufficiently broad to ensure that no serious question of application arises in the vast range of cases...").

27. Barry, Toward Universalism, at 225 n.123. 
on account of impairments that "can be expected to result in death or [that have] lasted or can be expected to last for a continuous period of not less than 12 months." 28 The ADA, by contrast, is a civil rights law, not a benefits law. It does not provide cash benefits to those who cannot work; it provides antidiscrimination protection to those who can. ${ }^{29}$ By its terms, the ADA protects all those who face barriers - attitudinal, architectural, and so on-because of their impairments. ${ }^{30}$

Importantly, the ADA's definition of disability is not new. It was taken verbatim from an earlier federal law, $\$ 504$ of the Rehabilitation Act of 1973, which prohibits the federal government and recipients of federal funds from discriminating based on disability. ${ }^{31}$ Although the U.S. Supreme Court and lower courts had given the definition of disability an expansive reading under the Rehabilitation Act, these broad interpretations did not hold under the ADA. Instead, the Supreme Court and lower courts finely parsed the definition of disability, narrowing the ADA's scope of coverage to those with the most severely limiting impairments. ${ }^{32}$ As discussed in Part IV, these narrow interpretations spurred Congress to amend the ADA in 2008, greatly expanding the ADA's scope of coverage and what it means to be "disabled."

28. Social Security Act, 42 U.S.C. $\S 423(d)(1)(A)$ (providing disability insurance benefit payments to those with an "inability to engage in substantial gainful activity by reason of any medically determinable physical or mental impairment which can be expected to result in death or which has lasted or can be expected to last for a continuous period of not less than 12 months...").

29. Barry, Congress Intended, supra note 25. As further discussed below, ADA protection extends beyond employment to public services such as education and transportation, as well as to places of public accommodation like restaurants and hotels. See infra note 209 (discussing examples of ADA's comprehensive coverage).

30. See Americans with Disabilities Act of 1990 \& 2, 42 U.S.C. \$ 12101(a)(5) (2005) ("II]ndividuals with disabilities continually encounter various forms of discrimination, including outright intentional exclusion, the discriminatory effects of architectural, transportation, and communication barriers, overprotective rules and policies, failure to make modifications to existing facilities and practices, exclusionary qualification standards and criteria, segregation, and relegation to lesser services, programs, activities, benefits, jobs, or other opportunities ..."). See also ADA Amendments Act of 2008 § 2(a)(2), 42 U.S.C. § 12101 Historical and Statutory Notes (" $[\mathrm{I}] \mathrm{n}$ enacting the ADA, Congress recognized that physical and mental disabilities in no way diminish a person's right to fully participate in all aspects of society, but that people with physical or mental disabilities are frequently precluded from doing so because of prejudice, antiquated attitudes, or the failure to remove societal and institutional barriers.").

31. Rehabilitation Act of $1973 \S 504,29$ U.S.C. $\$ 794$ (2006) (prohibiting discrimination in federal programs based on disability); Rehabilitation Act Amendments of 1974 § 111(A), Pub. L. No. 93-513, 88 Stat. 1617 (codified in scattered sections of 29 U.S.C.); 29 U.S.C. § 705(20) (2006) (defining "individual with a disability"). Section 504 of the Rehabilitation Act "is just one part of a larger and complex statute that increased federal support for vocational and rehabilitation programs." Barry, Congress Intended, supra note 25.

32. Barry, Congress Intended, supra note 25. 


\section{GENDER IDENTITY DISORDER AND THE ADA OF 1990: ADA AS MORAL CODE}

Since 1990, the ADA has explicitly excluded from coverage the following list of impairments:

(1) transvestism, transsexualism, pedophilia, exhibitionism, voyeurism, gender identity disorders not resulting from physical impairments, or other sexual behavior disorders;

(2) compulsive gambling, kleptomania, or pyromania; or

(3) psychoactive substance use disorders resulting from current illegal use of drugs. ${ }^{33}$

While subpart (1) purports to exclude all "sexual behavior disorders," it notably includes Gender Identity Disorder (GID) (and Transsexualism, which was folded into the definition of GID in 1994 and is no longer used by the DSM) - which is not a sexual behavior disorder. ${ }^{34}$ Unlike the sexual

33. 42 U.S.C. $\$ 12211$ (b) (2006).

34. The classification "Gender Identity Disorders," and the three diagnoses within that classification, "Transsexualism," "Gender Identity Disorder of Childhood," and "Atypical Gender Identity Disorder," first appeared in the DSM in 1980. AM. PSYCHIATRIC ASS'N, DiAGNOSTIC AND STATISTICAL MANUAL OF MENTAL DISORDERS: DSM-III 261-66 (1980). The DSM-III, as it was called, considered "Gender Identity Disorders" to be a subclass of "Psychosexual Disorders," alongside "Paraphilias" such as pedophilia and voyeurism. Id. at 261-66. When the DSM was revised in 1987, the DSM-III-R removed "Gender Identity Disorders" from the subclass "Psychosexual Disorders" and instead listed it as a subclass of "Disorders Usually First Evident in Infancy, Childhood, or Adolescence." AM. PSYChIATRIC Ass'N, DiaGnOstic AND STATISTICAL MANual OF MENTAL DISORDERS: DSM-III-R 27, 71 (1987) [hereinafter DSMIII-R]. Paraphilias were listed as a subclass of "Sexual Disorders." Id. at 279. The DSM-III-R was the version of the DSM in effect at the time of the ADA's passage in 1990. This version also added a fourth diagnosis, "Gender Identity Disorder of Adolescence or Adulthood, NonTranssexual Type," which differed from "Transsexualism" in that the former did not involve a "persistent ... wish to get rid of one's primary and secondary sex characteristics and acquire the sex characteristics of the other sex." Id. at 77.

In 1994, a new version of the DSM, the DSM-IV, "replaced the diagnosis of 'Transsexualism' with 'Gender Identity Disorder." See AM. PSYCHIATRIC ASS'N, DIAGNOSTIC AND STATISTICAL MANUAL OF MENTAL DISORDERS: DSM-IV 532-38 (1994) [hereinafter DSMIV]. See also The Harry Benjamin International Gender Dysphoria Association's Standards of Care for Gender Identity Disorders, Sixth Version, TRANSGENDER LONDON, http://transgenderlondon.com/

HBSOC.htm. Despite its removal from the DSM-IV, the word "transsexual" continues to be used colloquially to refer to those "who seek to live in a gender different from the one assigned at birth and who may seek or want medical intervention (through hormones and/or surgery) for them to live comfortably in that gender." Teaching Transgender, NATIONAL CENTER FOR TRANSGENDER EQUALITY, 16 (Jan. 2009), http://transequality.org/Resources/NCTE_

Teaching_Transgender.pdf. Like its predecessor, the DSM-IV distinguished between "Gender Identity Disorders" and "Sexual Disorders." DSM-IV, supra note 34 at 493. The DSM-IV-TR maintains this distinction, see AM. PSYCHIATRIC ASS'N, DiAGNOSTIC AND STATISTICAL MANUAL 
disorders listed in subpart (1), all of which are characterized by "recurrent, intense sexual urges, fantasies, or behaviors that involve unusual objects, activities, or situations," GID is, as its name suggests, a gender identity disorder. ${ }^{35}$

According to the DSM-IV, GID is characterized by a "strong desire" to be "the other gender" and "clinically significant distress or impairment in social, occupational, or other important areas of functioning." 36 Like so many other mental impairments ${ }^{37}$ under review by the American Psychiat-

OF MENTAL DISORDERS: DSM-IV-TR 535 (2000), as do proposed changes to the DSM that will take effect in 2013, see Gender Dysphoria, DSM-5 Proposed Revision, supra note 10.

35. DSM-IV, supra note 34 , at 493,532 . By adding the words "not resulting from physical impairments" after "gender identity disorders," the ADA presumably covers those whose GID is attributable to intersex conditions (formerly known as "Hermaphroditism" and increasingly referred to by the medical community as "Disorders of Sex Development" (DSD)), which affect the sexual and reproductive anatomy. See 42 U.S.C. $\$ 12211(\mathrm{~b})(1)(2006)$. For a good discussion of intersex conditions, see Yamuna Menon, Note, The Intersex Community and the Americans with Disabilities Act, 43 CONN. L. REv. 1221, 1227-32 (2011), and Types of Intersex Conditions, TRANSFAITHONLINE, http://www.transfaithonline.org/intersections/intersex/types/. At least one court has suggested that the GID exclusion may not, in fact, exclude GID to the extent that GID "results 'from physical impairments' in an individual's genome." Doe v. Yunits, 25 Mass. L. Rptr. 278 n.6 (Super. Ct., 2001) ("In light of the remarkable growth in our understanding of the role of genetics in producing what were previously thought to be psychological disorders, this Court cannot eliminate the possibility that all or some gender identity disorders result 'from physical impairments' in an individual's genome."); see also Jennifer L. Levi \& Bennett $\mathrm{H}$. Klein, Pursuing Protection for Transgender Through Disability, in TRANSGENDER RIGHTS 84 (2006) (stating that ADA's inclusion "of gender identity disorders resulting from physical impairments offer some hope for protection as the physical etiology of gender identity disorder is more thoroughly researched and understood ...") (emphasis added).

36. DSM-IV, supra note 34 , at 537-38.

37. The terms "mental impairment" and "mental disorder" are not without ambiguity. They are sometimes used to refer to conditions impacting one's cognitive development, such as Intellectual Development Disorder (formerly known as "Mental Retardation"). See Intellectual Development Disorder: Proposed Revision, AM. PSYCHIATRIC Ass'N DSM-5 DEv. Proposed revisions are no longer available online, but are on file with the author. Please see dsm5.org for the final version of the rule. They are also used to refer to conditions impacting one's emotions or behavior, such as Major Depressive Disorder or Oppositional Defiant Disorder. See Major Depressive Disorder, Recurrent: Proposed Revision, AM. PSYCHIATRIC Ass'N DSM-5 Dev. Proposed revisions are no longer available online, but are on file with the author. See dsm5.org for the final version of the rule; Oppositional Defiance Disorder: Proposed Revision, AM. PsYchIATRIC ASS'N DSM-5 DEV. Proposed revisions are no longer available online, but are on file with the author. Please see dsm5.org for the final version of the rule. Here I use the terms "mental impairment" and "mental disorder" interchangeably to refer to conditions that impact cognition as well as emotions and behavior. This is consistent with the American Psychiatric Association's proposed revision to the definition of "mental disorder" in the DSM-5 as well as the U.S. Equal Employment Opportunity Commission's definition of "mental impairment" under the ADA. Compare Mental Disorder, DSM-5 Proposed Revision ("A Mental Disorder is a health condition characterized by significant dysfunction in an individual's cognitions, emotions, or behaviors that reflects a disturbance in the psychological, biological, or developmental processes underlying mental functioning."), with Regulations to Implement the Equal Employment Provisions of the Americans with Disabilities Act, 29 C.F.R. $\$ 1630.2(\mathrm{~h})(2011)$ (August 17, 2012) ("[M]ental impairment means ... [a]ny mental or psychological disorder, such as an intellectual disability (formerly termed 'mental retardation'), organic brain syndrome, emotional or mental illness, and specific learning disabilities."). 
ric Association, the diagnostic criteria for GID are in a state of flux. ${ }^{38}$ Under the proposed DSM-5, GID will be renamed "Gender Dysphoria," 39 which is less "stigmatizing" and "better reflects the core of the problem: an incongruence between, on the one hand, what identity one experiences and/or expresses and, on the other hand, how one is expected to live based on one's assigned gender (usually at birth)." 40 Rather than "presuppos[e] the existence of acute or inherent distress" associated with GID, the DSM-5 modifies the requirement of "clinically significant distress or impairment" to include "a significantly increased risk of suffering death, pain, disability, or an important loss of freedom." 41 According to the DSM-5's Working Group on Sexual and Gender Identity Disorders, not all people with GID are distressed and, according to some studies, they "generally function psychologically in the non-clinical range." 42 The Working Group further suggests that it is "stigma" that causes distress, not GID, and that the desire "to be rid of body parts that do not fit one's identity is, in the absence of data," not "inherent[ly] distress[ing]." 43 According to the proposed DSM-5, the "desire to be rid of one's primary and/or secondary sex characteristics because of a marked incongruence with one's experienced/expressed gender" may not only not be distressing - it may well be liberating.

Given the unlikely company in which GID (and Transsexualism) finds itself, one might guess that this list was not the result of careful congressional deliberation. And one would be right. This list was a slapdash collection of mental impairments drawn from the DSM-III- ${ }^{44}$ and grafted onto the ADA by amendment to ensure passage in the Senate. ${ }^{45}$ What follows

38. See Gender Dysphoria, DSM-5 Proposed Revision, supra note 10.

39. Id.

40. Gender Dysphoria, DSM-5 Rationale, supra note 10 (stating that DSM-5 Neurodevelopmental Disorders Working Group "received many favorable comments about the proposed name change, particularly with regard to the removal of the 'Disorder' label from the name of the diagnosis").

41. Compare Gender Dysphoria, DSM-5 Proposed Revision, supra note 10 with DSM-IV, supra note 34, at 537-38 (emphasis added).

42. Gender Dysphoria, DSM-5 Rationale, supra note 10; see id. ("[M]any individuals, after transition, do not meet any more the criteria set for gender dysphoria ....").

43. $1 d$.

44. See DSM-III-R, supra note 34.

45. 135 CONG. REC. S10785 (Sep. 7, 1989) (statement of Sen. Armstrong) ("Under this act the term 'disability' does not include 'homosexuality,' 'bisexuality,' 'transvestism,' 'pedophilia,' 'transsexualism,' 'exhibitionism,' 'voyeurism,' 'compulsive gambling,' 'kleptomania,' or 'pyromania,' 'gender identity disorders,' current 'psychoactive substance use disorders,' as defined by DSM-III-R which are not the result of medical treatment, or 'other sexual behavior disorders." ). Because the Senate also passed Senator Jesse Helms' amendment to the ADA excluding "transvestites" from coverage, see 135 CONG. REC. S10,776 (daily ed. Sep. 7, 1989), the ADA excludes "transvestism" twice. See id. at S10776; see also Colker, Homophobia, supra note 9, at 50 (stating that this "redundancy is itself derogatory because it highlights the legislators' extreme desire to prevent this group from having legal protection."); Robert Burgdorf, The Americans with Disabilities Act: Analysis and Implications of a Second-Generation Civil Rights Statute, 26 HARV. C.R.-C.L. L. REV. 413, 519 (1991) ("No evidence suggests that Congress inves- 
is a discussion of how that list came to be. Because much of this story has not been told, I discuss it in some detail. 46

\section{A. Excluding Mental Impairments: The Senate Floor}

To understand why GID was excluded from the ADA, it is first necessary to understand legislators' objections to mental impairments more generally. As the ADA progressed through the Senate Committee on Labor and Human Resources, no attempt was made to exclude particular impairments, mental or physical. ${ }^{47}$ In fact, Congress deliberately went in the opposite direction, including all impairments so long as they actually limited, previously limited, or were regarded as limiting a major life activity. ${ }^{48}$ According to the Senate Committee on Labor and Human Resources Report:

It is not possible to include in the legislation a list of all the specific conditions, diseases, or infections that would constitute physical or mental impairments because of the difficulty of ensuring the comprehensiveness of such a list, particularly in light of the fact that new disorders may develop in the future. The term includes, however, such conditions, diseases and infections as: mental retardation, emotional illness, specific learning disabilities, drug addiction, and alcoholism. ${ }^{49}$

Disability rights advocates, therefore, had no indication of efforts to exclude impairments. 50

This all changed during the Senate floor debate on the ADA on September 7, 1989. Late in the day, Senator William Armstrong (R-CO) came to the floor and expressed his concerns with the ADA's definition of disabilityspecifically, its coverage of certain mental impairments. ${ }^{51}$ Several other

tigated such conditions, except, perhaps, for the problem of illegal drug use. Consequently, it is arguable that the members of Congress relied upon nothing other than their own negative reactions, fears and prejudices in fashioning the list of excluded classes.").

46. For two helpful articles discussing the legislative history of the GID exclusion, see Colker, Homophobia, supra note 9, at 36-44, and Kari E. Hong, Categorical Exclusions: Exploring Legal Responses to Health Care Discrimination Against Transsexuals, 11 COLUM. J. GENDER \& L. 88, 117-118 (2002).

47. Telephone Interview with Chai Feldblum, Professor of Law, Georgetown University Law Center (Oct. 10, 2011) [hereinafter Feldblum Interview].

48. See S. Rep. No. 101-116, at 20 (1989) (defining disability to mean "(1) A physical or mental impairment that substantially limits one or more of the major life activities of such individual; (2) A record of such impairment; or (3) Being regarded as having such an impairment").

49. Id.

50. Feldblum Interview, supra note 47. See also 135 CONG. REC. S10785 (daily ed. Sep. 7, 1989) (statement of Sen. Hatch) (noting that ADA's "sweeping" inclusion of all mental impairments was "ignored" until Armstrong raised this issue during floor debate).

51. 135 CONG. REC. S10753 (daily ed. Sep. 7, 1989). 
senators shared his concerns, which were of three types: moral, legal, and pragmatic.

1. The Moral Case for Excluding Certain Mental Impairments

Armstrong's first concern with the ADA's coverage of certain mental impairments was a moral one. Armstrong "could not imagine the sponsors would want to provide a protected legal status to somebody who has such [mental] disorders, particularly those [that] might have a moral content to them or which in the opinion of some people have a moral content." 52 According to Armstrong, although "the ideals of our country certainly call upon the Senate to do whatever it can to be helpful to people in wheelchairs or who have some kind of a physical disability or handicap of some sort and who are trying to overcome it," the ADA extended coverage to "[m]ental disorders, such as alcohol withdrawal, delirium, hallucinosis, dementia with alcoholism, marijuana, delusional disorder, cocaine intoxication, cocaine delirium, [and] disillusional disorder," which "by any ordinary definition we would not expect to be included." 53

In a colloquy with Senator Harkin, Senator Armstrong expressed concern with still more "mental disorders," namely, current drug and alcohol abuse, "homosexuality and bisexuality . . . exhibitionism, pedophilia, voyeurism ... compulsive kleptomania, or other impulse control disorders ... conduct disorder, [and] any other disruptive behavior disorder. . .. ${ }^{154}$ Senator Harkin responded that none would be covered except for conduct disorder or other disruptive behavior disorder to the extent it was "closely connected with a mental disorder." 55 Senator Armstrong stated that he would submit a list of mental impairments to Senator Harkin for exclusion from the ADA, and would offer an amendment if "there [was] any doubt" as to their exclusion. 56

Senator Warren Rudman (R-NH) shared Armstrong's concerns, particularly with regard to the coverage of alcoholism, drug addiction, compulsive gambling, pedophilia, kleptomania, and other "socially unacceptable, often illegal, behavior." According to Senator Rudman:

A diagnosis of certain types of mental illness is frequently made on the basis of a pattern of socially unacceptable behavior and lacks any physiological basis. In short, we are talking about behavior that is immoral, improper, or illegal and which individuals are engaging in of their own volition, admittedly for reasons we do not

52. Id. (statement of Sen. Armstrong).

53. 1d.

54. Id. at $\mathrm{S10754.}$

55. Id.

56. Id. 
fully understand. Where we as a people have through a variety of means, including our legal code, expressed disapproval of certain conduct, I do not understand how Congress can create the possibility that employers are legally liable for taking such conduct into account when making employment-related decisions. In principle, I agree with the concept that the mentally ill should be protected from in[v]idious discrimination just as the physically handicapped should be. However, people must bear some responsibility for the consequences of their own actions. ${ }^{57}$

Echoing Senator Armstrong's and Rudman's moral concerns, Senator Jesse Helms (R-NC) pressed the sponsors on the ADA's presumptive coverage of five groups of individuals: "homosexuals"; "transvestites"; illegal drug users and alcoholics; "people who are HIV positive or have active AIDS disease"; and those with "psychosis, neurosis, or other mental, psychological disease[s] or disorder[s]," namely, pedophilia, schizophrenia, kleptomania, manic depression, intellectual disabilities, and psychotic disorders. ${ }^{58}$ According to Senator Helms,

If this were a bill involving people in a wheelchair or those who have been injured in the war, that is one thing. But how in the world did you get to the place that you did not even [ex]clude transvestites? How did you get into this business of classifying people who are HIV positive, most of whom are drug addicts or homosexuals or bisexuals, as disabled? ... What I get out of all of this is here comes the U.S. Government telling the employer that he cannot set up any moral standards for his business by asking someone if he is HIV positive, even though 85 percent of those people are engaged in activities that most Americans find abhorrent. .. [H]e cannot say, look I feel very strongly about people who engage in sexually deviant behavior or unlawful sexual practices..$^{59}$

Senator Helms questioned whether, by covering these impairments, the ADA deprived an employer of "the right to run his company as he sees fit," including "mak[ing] a judgment about [his] . . . employees" based on his "own moral standards." 60

Senator Harkin assured Senator Helms that, even absent an explicit exclusion, homosexuality and bisexuality were not covered by the ADA - not for moral reasons, but for medical ones. "[B]ehavior characteristics" such

57. Id. at S10796 (statement of Sen. Rudman).

58. Id. at S10765 (statement of Sen. Helms).

59. Id. at $\$ 10768, S 10772$.

60. Id. at $\mathrm{S} 10765$. 
as "homosexuality and bisexuality are not disabilities under any medical standards." 61 Senator Harkin immediately accepted, without any debate, Senator Helms' amendment excluding "transvestites," citing Helms' identical amendment excluding transvestites from the Fair Housing Act the previous year. ${ }^{62}$ Senator Harkin also reluctantly agreed to Helms' conforming amendment excluding from the Rehabilitation Act those currently using illegal drugs. ${ }^{63}$ By contrast, Senators Harkin and Kennedy strongly defended the ADA's coverage of HIV/AIDS, noting that such coverage was "completely consistent with public health policy." 64 "If we fail to provide this protection," Senator Kennedy warned, "we will continue to drive this epidemic underground." 65 As a result, no amendment was offered to exclude HIV/AIDS during the Senate floor debate. 66

61. Id. at S10786 (statement of Sen. Harkin); see also supra note 26 and accompanying text. The decision to exclude homosexuality and bisexuality from the ADA was consistent with the treatment of sexual orientation under the Rehabilitation Act. See H.R. REP. NO. 101-596, at 88 (1990) (Conf. Rep.) ("The Senate bill restates current policy under section 504 of the Rehabilitation Act of 1973 that the term 'disability' does not include homosexuality and bisexuality.").

62. 135 CONG. REC. at S10765; see also Colker, Homophobia supra note 9, at 39 (discussing Senate floor debate on Fair Housing Amendments Act of 1988 and overwhelming support for Helms' amendment, which passed by vote of 89-2). Interestingly, Senator Helms did not express similar opposition to the protection of Transsexualism and GID, both of which were classified as mental disorders in the DSM at the time of passage of the Fair Housing Amendments Act (FHAA) and the ADA. See supra note 34. Helms' amendment to the FHAA, like his amendment to the ADA one year later, excluded only "transvestites." 135 CONG. REC. at S10765.

Senator Helms also expressed opposition to protection for "transvestites" during the floor debate over whether to override President Ronald Reagan's veto of the Civil Rights Restoration Act of 1987. 134 CONG. REC. S4236 (daily ed. Mar. 17, 1988) (statement of Sen. Helms) (objecting to courts' interpretation of Rehabilitation Act's definition of disability to include "transvestism and other compulsions or addi[c]tions, which churches or religious schools might once have felt comfortable in regarding as moral problems, not mental handicaps"); id. ("When people ... think of handicaps, what first comes to mind are diseases which have no conceivable moral content and yet have been associated in the past with irrational fears - such as epilepsy - or else physical impairments. ... But now we propose ... to open for the courts the opportunity to eliminate the entire concept of a moral qualification for any job, position, or privilege ... by referring to the strong trend in psychiatry to classify almost all compulsive or destructive behavior patterns as discrete and medically treatable diseases.").

63. 135 CONG. REC. at S10765 ("[T]he war on drugs will be lost if those who abuse drugs are allowed to hide behind laws designed to help those who are seriously handicapped," such as "the mentally retarded, the deaf, the blind, and those with muscular dystrophy.") (statement of Sen. Helms); see id. (statement of Sen. Harkin) ("I must say to the Senator I would have preferred not to amend any other statute [i.e., the Rehabilitation Act] during the consideration of [the ADA]; a position, which I might add, with which the administration concurs.").

64. Id. at $S 10768$ (statement of Sen. Kennedy); id. at S10772 (statement of Sen. Harkin).

65. Id. at $\mathrm{S} 10768$ (statement of Sen. Kennedy).

66. During the floor debate in the House, coverage of HIV/AIDS was again in controversy-this time for health reasons, not moral ones. "Some representatives claimed that the bill would bankrupt the restaurant industry by forcing employers to hire individuals who are HIV-positive, which would cause the public to perceive that their food was unsafe." Colker, Homophobia, supra note 9, at 46. Representative Jim Chapman (D-TX) offered an amendment allowing a food service employer to deny employment to a person "with an infectious or communicable disease of public health significance," which would have included people with 
In response to Senator Helms' opposition to the inclusion of various mental impairments, Senator Harkin explained that "some people only think of people who are physically disabled as being handicapped. People can be mentally handicapped as well." 67 He elaborated:

There is a wellspring of fears and unfounded prejudices about people with disabilities, unfounded fears, whether people have mental disorders, whether they are manic depressives or schizophrenia or paranoia, or unfounded fears and prejudices based upon physical disabilities. The point of the [ADA] is to start breaking down those barriers of fear and prejudice and unfounded fears, to get past that point so that people begin to look at people based on their abilities, not first looking at their disability. ${ }^{68}$

For example, Senator Harkin added, manic depression might be "completely controlled [by] ... prescription drugs." 69

Senator Pete Domenici (R-NM) likewise defended the ADA's inclusion of mental impairments, explaining that other types of discrimination "just scratch the surface in terms of the suffering that goes on in the lives of people who are assumed to be disabled because of . . . serious mental illness."70 Noting that Winston Churchill and Abraham Lincoln were almost certainly "manic-depressive," and that "hundreds of thousands of Americans today . . . have been diagnosed or are being treated for manic-depression, bipolar effective disease or schizophrenia," Senator Domenici stated that "the time has arrived in the United States when people who have mental illnesses ... [should] not be automatically discriminated against for employment in this country."71

HIV/AIDS. 136 CONG. REC. H2478 (daily ed. May 17, 1990) (statement of Rep. Chapman). The House approved the Chapman amendment. Id. at H2483-84. When the bill went to conference, the Chapman amendment was removed, despite its support among senators, including Helms and Armstrong. 136 CONG. REC. S9535, S9544 (daily ed. July 11, 1990) (statement of Sen. Helms). When the Conference Report returned to the Senate for consideration, Senator Hatch proposed a toothless (for people with HIV) version of the Chapman amendment, which allowed an employer to deny employment to a person with an infectious or communicable disease only if the disease is one that is "transmitted to others through the handling of food" as determined by the Secretary of Health and Human Services. 136 CONG. REC. 9532 (1990); see Colker, Homophobia, supra note 9, at 48. Hatch's amendment passed the Senate, was adopted at the second Conference, and became law. 42 U.S.C. \$ 12113(e) (2006); see Colker, Homophobia, supra note 9 , at $48-49$.

67. 135 CONG. REC. S10768 (daily ed. Sep. 7, 1989) (statement of Sen. Harkin).

68. 1 d.

69. Id. at $\mathrm{S} 10766$.

70. Id. at $\$ 10779$ (statement of Sen. Domenici).

71. Id. 


\section{The Legal Case for Excluding Mental Impairments}

Senator Armstrong's second concern with covering mental impairments was a legal one. According to Armstrong, civil rights laws traditionally deal "with very clear-cut, readily discernible categories," like "race, religion, and sex.... A person is or is not a man or a woman. A person is or is not a Catholic, a Jew, a Mormon, whatever, a Baptist, a Presbyterian. That is something we can readily determine. A person either is or is not Irish, Italian, and so on."72 Rather than "list[ing] the specific protected categories," Armstrong explained, the ADA "proceeds from an entirely different point of view" by including "a very broad vague definition" of disability that extends civil rights protection "in a very broad and [] unquantified way."73 Specifically, the ADA "protects all mental impairments that substantially limit a major life activity," which, according to Armstrong, meant that voyeurism, pedophilia, compulsive gambling and the "vast numbers of mental disorders" contained in that "great, fat book called the [DSM-III-R]" were "in" the ADA unless Congress took them out.74

Noting that the ADA's coverage of mental impairments was "appealing to the heart" but ought to "give our heads some concern," Armstrong added that he planned to introduce an amendment "that will take voyeurism and some other things out." 75

Significantly, no one challenged Armstrong's characterization of civil rights laws. No one pointed out that civil rights laws protect all races, including white people; all religions, including atheists; and all sexes, including men. ${ }^{76}$ No one argued that the ADA's applicability to mental impairments was therefore consistent with traditional civil rights law, not at odds with it. Furthermore, no one took issue with Armstrong's assumption that having (or having a history of, or being regarded as having) a mental impairment, by itself, meant that one was covered under the statute. In order to be considered "disabled," and therefore covered, the ADA requires more than just a mental impairment. It requires that the mental impairment substantially limit a major life activity (under prongs 1 and 2) or that a person be regarded as having a substantially limiting impairment (prong 3 ). ${ }^{77}$

72. 135 CONG. REC. S10772 (daily ed. Sep. 7, 1989) (statement of Sen. Armstrong).

73. Id.

74. 135 CONG. REC. S11174, S11176 (daily ed. Sep. 14, 1989) (statement of Sen. Armstrong).

75. 135 CONG. REC. S10772-73 (daily ed. Sep. 7, 1989) (statement of Sen. Armstrong).

76. See e.g., McDonald v. Santa Fe Trail Transp. Co., 427 U.S. 273, 278-79 (1976) ("Title VII of the Civil Rights Act of $\mathbf{1 9 6 4}$ prohibits the discharge of 'any individual' because of 'such individual's race' .... Its terms are not limited to discrimination against members of any particular race.") (internal citations omitted).

77. See S. Rep. No. 101-116, at 20 (1989) (defining disability as "a physical or mental impairment that substantially limits one or more of the major life activities of such individual, a record of such an impairment, or being regarded as having such an impairment"); accord. Americans with Disabilities Act of 1990 §3(2), 42 U.S.C. § 12102(2) (2005). 


\section{The Pragmatic Case for Excluding Mental Impairments}

Armstrong's third concern with the ADA's coverage of mental impairments was a pragmatic one. Given the vast and ever-changing array of mental impairments, Armstrong warned of the ADA's invitation to a flood of litigation. ${ }^{78}$ In a statement published seven days after passage of the ADA, Armstrong stated that the ADA's protection of "all mental impairments that substantially limit a major life activity will have the most farreaching and potentially disruptive effects on private decisionmakers. . . [T] he private sector will be swamped with mental disability litigation." 79 According to Armstrong, private employers had better "prepare [them]selves for lawsuits based on the following types of mental conditions": compulsive gambling, ${ }^{80}$ acrophobia (fear of heights) and other phobias; depressive neurosis ${ }^{81}$; paranoid schizophrenia; manic depression; borderline personality disorder; "sexual disorders: transvestism and transexualism"; schizoid personality disorder; stress disorders; and a catchall "miscellaneous mental disorders." 82

For each, Armstrong cited one or more cases in which courts found people alleging discrimination based on those mental impairments to be covered under the Rehabilitation Act. "In the reported cases," Senator Armstrong noted,

persons with mental impairments often lose their cases because they are found not to be "otherwise qualified" for the position or

78. See 135 CONG. REC. S11174-75 (daily ed. Sep. 14, 1989) (statement of Sen. Armstrong). Senators Helms, Rudman, and Humphrey made similar arguments. See 135 CONG. REC. S10755 (daily ed. Sep. 7, 1989) (statement of Sen. Helms) (stating that ADA would lead to the "persecution of some small businessman" by "a horde of bureaucrats"); id. at $\$ 10783$ (stating that ADA's coverage of "drug addicts and alcoholics . . . schizophrenics, manic depressives, and persons with extremely low IQ's[,] . . . persons with deadly infectious diseases, like AIDS . .. [and people with] virtually any mental or physical shortcoming . . . will deter employers from preserving high standards of fitness, safety, and efficiency within their work force") (statement of Sen. Humphrey); id. at $\mathbf{S 1 0 7 9 6}$ (statement of Sen. Rudman) (stating that "[a]s a matter of law, this country has always granted employers a wide degree of latitude in making employment-related decisions, including the right to make judgments based on non-work related behavior. To limit this right based on the diagnosis of a mental illness or chemical dependency may be opening up a Pandora's box.").

79. 135 CONG. REC. S11174, S11176 (daily ed. Sep. 14, 1989) (statement of Sen. Armstrong).

80. Compulsive gambling, of course, had already been excluded by Armstrong's amendment no. 722. See supra note 45 and accompanying text (discussing passage of amendment excluding "compulsive gambling" from definition of disability under ADA). Armstrong may have included compulsive gambling in his subsequent statement out of concern that the House would not incorporate a similar exclusion.

81. "Depressive Neurosis," defined in DSM-II as "an excessive reaction of depression due to an internal conflict or to an identifiable event such as the loss of a love object or cherished possession" was replaced by "Dysthymic Disorder" in DSM-III. See W. EDWARD CRAIGHEAD ET AL., PSYCHOPATHOLOGY: HISTORY, DIAGNOSIS, AND EMPIRICAL FOUNDATIONS 332 (2008).

82. 135 CONG. REC. S11175-76 (daily ed. Sep. 14, 1989) (statement of Sen. Armstrong). 
benefit they seek. On the other hand, sometimes they win. In either case, $\mathrm{S} .933$ gives persons with mental impairments a statutory basis for a lawsuit whenever a private employer or private provider of public accommodations takes an action that the impaired person[] believes is to his or her detriment and based on his or her disability. 83

Implicit in Armstrong's case summaries is the belief that discrimination claims brought by people with mental impairments are inherently frivolous, and that such plaintiffs should never win. It is not "discrimination" when an employer fires or refuses to hire or accommodate a person with a mental impairment, Armstrong seems to argue - it is good business. Better, then, to dispose of such "egregious lawsuits" at the outset, rather than have to defend them through "litigation which is costly and time consuming." 84

Because Armstrong submitted his case summaries into the record several days after the Senate passed the Americans with Disabilities Act, no senator ever challenged his interpretation of the cases. Had the ADA's sponsors had the opportunity to parse those cases, a different story might have unfolded - a story about cases that were not frivolous but tragic, and nothing to suggest a flood of litigation. ${ }^{85}$

For example, under the heading "Sexual Disorders," Senator Armstrong objected to the holdings of two cases that acknowledged that "transexualism" and "transvestism," respectively, were covered "disabilities"' under the Rehabilitation Act.86 In Doe v. United States Postal Service, the plaintiff, a male-to-female transsexual, had her conditional job offer revoked after she disclosed her intent to transition to the other sex and suggested that she be allowed to work as a woman rather than changing her physical appearance during her employment. ${ }^{87}$ Describing the case as a "sad" one, the United States District Court for the District of Columbia denied the United States Postal Service's motion to dismiss and held that the plaintiff stated a claim for "disability" discrimination. ${ }^{8}$

In Blackwell v. U.S. Department of the Treasury, a Treasury Department supervisor canceled a job vacancy just hours after interviewing the plaintiff, a "transvestite" male who dressed in feminine clothing. ${ }^{89}$ Notwithstanding the plaintiff's priority hiring credentials (the plaintiff had worked for nearly ten years in other branches of the Treasury Department, and had been laid

83. Id. at $\mathrm{S} 11174$.

84. Id. at $\mathrm{S} 11176$

85. See Sutton v. United Airlines, 527 U.S. 471, 511 (Stevens, J., dissenting) ("[I]t is hard to believe that providing individuals with one more antidiscrimination protection will make any more of them file baseless or vexatious lawsuits.").

86. 135 CONG. REC. S11174-75 (daily ed. Sep. 14, 1989) (statement of Sen. Armstrong).

87. No. 84-3296, 1985 WL 9446 at *1 (D.D.C. June 12, 1985).

88. Id. at ${ }^{\star} 1, * 3$.

89. 656 F. Supp. 713,714 (D.D.C. 1986). 
off due to a reduction in force), and over the recommendation of an experienced, competent interviewer that the plaintiff be hired, the Department supervisor "changed the rules to avoid the inevitable administrative hassle that would occur if he declined a qualified applicant .... [The supervisor] knew [the] plaintiff could do the job and had no sound basis for even refusing to accept him for the job." 90 Characterizing the Treasury Department's actions as "highly reprehensible," the United States District Court for the District of Columbia nevertheless held that, while transvestism was a covered disability under the Rehabilitation Act, the plaintiff was not entitled to relief because he had not shown that he was refused hire on that basis. ${ }^{91}$ According to the court, the plaintiff was instead refused hire "because [the supervisor] believed he was a homosexual (a condition not protected under the Rehabilitation Act)." 92 Significantly, the court acknowledged what it called the "underlying injustice" of its decision, and called on "wiser heads" to "correct" it.93

While indicating that neither "transexualism" nor "transvestism" should be a covered "disability," Armstrong never gave a reason for his objection. He never explained why it was right for the employers in Doe and Blackwell to refuse to hire the plaintiffs based on transsexualism or transvestism, despite the fact that both plaintiffs were eminently qualified to perform their jobs (i.e., the plaintiff in Doe had received and accepted her job offer, and the plaintiff in Blackwell was recommended for hire). ${ }^{94}$ Rather than "sad" and "reprehensible," or an "injustice" to be corrected, Armstrong suggested that the actions of the employers in both cases were beyond repute. ${ }^{95}$

Another of Armstrong's case summaries dealt with compulsive gambling.96 In Rezza v. U.S. Department of Justice, an FBI agent was fired for gambling away $\$ 2,000$ in government funds in Atlantic City, and he sued his employer under the Rehabilitation Act for discriminating against him based on his compulsive gambling. ${ }^{97}$ The U.S. District Court for the Eastern District of Pennsylvania indicated that compulsive gambling could be a covered disability and denied the FBI's motion for summary judgment based on material facts at issue regarding whether the agent was qualified to perform the job. ${ }^{98}$

Notwithstanding compulsive gambling's firm place under the DSM-III$\mathrm{R}$, Senator Armstrong attacked the premise that compulsive gambling was

90. Id. at 715 .

91. Id.

92. Id.

93. Id.

94. See Doe, 1985 WL 9446 at ${ }^{\star} 1$; Blackwell, 656 F. Supp. at 714.

95. Doe, 1985 WL 9446, at *1; Blackwell, 656 F. Supp. at 715; 135 CONG. REC. $\$ 11175$ (daily ed.

Sep. 14, 1989) (statement of Sen. Armstrong).

96. 135 CONG. REC. S11175 (daily ed. Sep. 14, 1989) (statement of Sen. Armstrong).

97. No. 87-6732, 1988 WL 48541, at 1 (E.D. Pa. May 16, 1988).

98. Id. at ${ }^{*} 1, * 6$. 
an impairment at all and implied that, even if it were, such an impairment rendered a person per se unqualified. ${ }^{99}$ What Armstrong did not say was that the agent was a twenty-two-year veteran of the FBI with an "otherwise fine record of FBI and prior military service" and that, immediately following the incident, the agent entered a 22-day treatment program. ${ }^{100}$ When the agent returned to active duty, he performed his duties satisfactorily, attended Gamblers Anonymous twice a week, and no longer gambled. ${ }^{101}$ Senator Armstrong also failed to note that the FBI's Philadelphia director recommended against the agent's dismissal. ${ }^{102}$

In light of these facts, it seems far less clear whether the agent's gambling history necessarily disqualified him from serving in the FBI. Contrary to Armstrong's critique, the court's decision to defer judgment pending receipt of more facts regarding the agent's qualifications seems entirely reasonable. Armstrong's proposed denial of coverage of all claims involving compulsive gambling, by contrast, seems too crude a tool to root out meritless claims - a knee-jerk response that would eliminate many legitimate claims (especially considering the other tools provided by the ADA, including the qualification requirement and direct threat defense). ${ }^{103}$

The remaining cases cited by Armstrong provide even less support for his proposed blanket exclusion of various mental impairments. In each case, the plaintiff was found "disabled" under the Rehabilitation Act but "not qualified" to perform the job. 104 Far from proving abuse of the law, these cases demonstrate the Rehabilitation Act's balanced approach: to

99. See 135 CONG. REC. S11175 (daily ed. Sep. 14, 1989) (statement of Sen. Armstrong) (rejecting reasoning of case in which court refused to grant summary judgment to federal government under Rehabilitation Act, in part, because issue of fact remained as to whether compulsive gambler was "otherwise qualified" to be FBI agent) (citing Rezza).

100. Rezza, 1988 WL 4851 at *1 n.2

101. Id. at ${ }^{\star} 1$

102. Id.

103. See Americans with Disabilities Act of 1990, Pub. L. No. 101-336 \$103 (1990). Several other cases cited by Armstrong likewise support the legitimacy of discrimination claims involving various mental impairments and the importance of reaching the merits in these cases. See, e.g., Majors v. Hous. Auth. of DeKalb Ga., 652 F.2d 454, 458 (5th Cir. 1981) (holding that material facts were at issue regarding whether tenant with mental impairment requiring companionship of dog was disabled, whether she was otherwise qualified to live in housing complex that prohibited dogs, and whether housing authority failed to reasonably accommodate her); Balzac v. Columbia Univ. Press, 495 N.Y.S.2d 45, 45 (App. Div. 1985) (holding that material facts were at issue regarding whether sales representative with manic depression, who was terminated on same day he returned from treatment and hospitalization, was qualified to perform his job); Barnes v. Barbosa, 494 N.E.2d 619, 623 (Ill. App. Ct. 1986) (holding that, under Illinois's Human Rights Act, bus driver with phobic reaction to carbon monoxide was disabled, and remanding case for determination of whether bus company discriminated against driver by not allowing him to transfer to another position within the company). But see Forrisi v. Bowen, 794 F.2d 931, 935 (4th Cir. 1986) (declining to reach merits and holding that utility worker with acrophobia, or fear of heights, who was terminated because he could not climb ladders to certain heights was not disabled).

104. See 135 CONG. REC. S11175-76 (daily ed. Sep. 14, 1989) (statement of Sen. Armstrong). 
make out a successful claim of disability discrimination, one must show not only that one is "disabled," but also that one is qualified to perform the job, which is no easy feat. For example, in Doe v. Region 13 Mental Health-Mental Retardation Commission, the Fifth Circuit Court of Appeals affirmed a district court judgment upholding a mental health center's decision to terminate a staff psychologist with depressive-neurosis who threatened to commit suicide. ${ }^{105}$ The Fifth Circuit Court of Appeals easily concluded that the staff member had a "disability" under the Rehabilitation Act, but held that she was not "otherwise qualified" to perform her job.106 Notwithstanding the staff member's consistently "outstanding" job reviews, the court credited her treating physician's testimony that she was "severely depressed and suicidal" and therefore a threat to herself and her patients. ${ }^{107}$

Similarly, in Doe v. New York University, the Second Circuit reversed a district court injunction ordering NYU Medical School to admit a medical student with bipolar disorder because of a history of self-destructive and anti-social behavior. ${ }^{108}$ In that case, the court concluded that the student had a disability but suggested that she was not "otherwise qualified" for admission to the school. 109 Despite supporting affidavits from several treating psychiatrists and the non-recurrence of symptoms in recent years while the plaintiff earned a masters degree from Harvard and worked for the federal government, the court found evidence that there was a "significant risk that [she would] have a recurrence of her mental disorder, with resulting danger to herself and to others with whom she would be associated as a medical student." 110

105. Doe v. Region 13 Mental Health-Mental Retardation Com'n, 705 F.2d 1402, 1404-05 (5th Cir. 1983).

106. Id. at $1408,1412$.

107. Id. at 1409 .

108. Doe v. New York Univ., 666 F.2d 761, 772 (2d Cir. 1981).

109. Id. at 779 .

110. Id. at 777; see also Fields v. Lyng, 705 F. Supp. 1134, 1137 (D. Md. 1988) (assuming, arguendo, that labor negotiator with behavioral disorder that resulted in "anxiety over travel and a propensity to shoplift, or kleptomania" was disabled, and holding that employee was not qualified because "he cannot travel safely or be trusted as a negotiator" and that, in any event, his employer reasonably accommodated him); Franklin v. U.S. Postal Service, 687 F. Supp. 1214, 1218 (S.D. Ohio 1988) (holding that postal worker with paranoid schizophrenia was disabled but not qualified because she refused to take medication, had excessive unexcused absences, and lashed out at co-workers and members of the public, and that, in any event, her employer reasonably accommodated her); Matzo v. Postmaster General, 685 F. Supp. 260, 263 (D.D.C. 1987) (holding that legal secretary with manic depression was disabled but not qualified due to excessive absences, irregular attendance, and insubordination; and holding that, in any event, her employer reasonably accommodated her); Swann v. Walters, 620 F. Supp. 741,747 (D.D.C. 1984) (holding that computer operator with paranoid schizophrenia, whose job required security clearance and involved access to highly sensitive medical records, was disabled but not qualified because of his conviction for child sex abuse); Boyd $\mathrm{v}$. U.S. Postal Service, No. 82-126R, 1983 WL 636, at *1, *8 (W.D. Wash. Aug. 1, 1983) (holding that postal worker with post-traumatic stress disorder was disabled but not qualified due to poor work history; and holding that, in any event, his employer reasonably accommodated him); 
Rather than allow courts to engage in the careful consideration of qualifications demanded by these cases, Armstrong suggested that these cases ought to be foreclosed altogether by denying anyone with a mental impairment a cause of action. ${ }^{111}$ "Who is a judge to believe?" Armstrong asked rhetorically. ${ }^{112}$ His answer: the employer - every time.

Significantly, Armstrong offered no support for his argument that coverage of various mental impairments would necessarily lead to a deluge of claims. ${ }^{113}$ The cases cited by Armstrong indicate no flood of litigation under the Rehabilitation Act with respect to such impairments and, even if they did, Congress has never seen the potential for lawsuits "as reason to restrict classes of antidiscrimination coverage." 114 Furthermore, if litigation were Armstrong's primary concern, EEOC charge statistics indicate that Armstrong should have targeted orthopedic impairments, not (or not only) mental ones. ${ }^{115}$

\section{B. Excluding GID: The Untold Story of the Senate Antechamber}

Behind the scenes and very late in the day, Senator Armstrong circulated his proposed amendment - a "long list of various kinds of conduct... . extracted from the DSM III[-R]" - to the bill's sponsors, Senators Harkin, Kennedy, Dole, and Hatch. ${ }^{116}$ According to Professor Chai Feldblum, one of the lead advocates for the disability rights community, Senator Armstrong's list consisted of "four pages of mental impairments literally copied from the pages of the DSM-III-R."117 Disability rights advocates recom-

Schmidt v. Bell, No. 82-1758, 1983 WL 631, at *10-*13 (E.D. Pa. Sep. 9, 1983) (holding that student loan collector with post-traumatic stress disorder was disabled but not qualified because of his behavioral and attitudinal problems and failure to adhere to routine office policy and procedure); Guerriero v. Schultz, 557 F. Supp. 511, 513 (D.D.C. 1983) (holding that foreign service officer with schizoid personality disorder and history of alcoholism was disabled but not qualified because, among other things, he could not travel on account of his need for continuing therapy in U.S.); Forrisi v. Bowen, 794 F.2d 931, 935 (4th Cir. 1986) (holding that utility worker with acrophobia, or fear of heights, who was terminated because he could not climb ladders to certain heights was not disabled (under "regarded as" prong) because he could perform other jobs).

111. See 135 CONG. REC. S11175-76 (Sep. 14, 1989) (statement of Sen. Armstrong).

112. Id.

113. See id. at S11174.

114. Sutton v. United Airlines, 527 U.S. 471, 511 (Stevens, J., dissenting).

115. U.S. EQuAl EMP. OPPORTUNITY COM'N, OfFICE OF RESEARCH, INFORMATION, AND Planning, ADA Charge Data by IMPairment/Bases - ReCeIPTS FY 1997-FY 2011, http:/ / eeoc.gov/eeoc/statistics/enforcement/ada-receipts.cfm (last visited June 4, 2012).

116. 135 CONG. REC. S10772 (daily ed. Sep. 7, 1989) (statement of Sen. Kennedy).

117. Feldblum Interview, supra note 47. As Legislative Counsel with the American Civil Liberties Union in Washington D.C. and Staff Attorney with the ACLU AIDS Project, Professor Feldblum was "the lead legal counsel for the disability and civil rights communities in Washington. D.C. during the three-year negotiations on the Americans with Disabilities Act." Chai R. Feldblum, Medical Examinations and Inquiries Under the Americans with Disabilities Act: A View from the Inside, 64 TEMP. L. REV. 521, 521 n. (1991). 
mended to the bill's sponsors that Senator Armstrong's proposed amendment "be put to an up or down vote," which they predicted would fail handedly. ${ }^{118}$

The sponsors' staff responded that they "wanted to negotiate the amendment with Senator Armstrong." 119 When disability rights advocates explained that the proposed amendment was "nothing more than a laundry-list of mental impairments and that there was nothing to negotiate," the sponsors reiterated that a "negotiation was the only option" at that point. Further, it was made clear that "homosexuality and bisexuality needed to be in the negotiated list of exclusions." 120

Disability rights advocates whittled down Senator Armstrong's fourpage list of exclusions to approximately five conditions. ${ }^{121}$ As required by the bill's sponsors, homosexuality and bisexuality were among the excluded conditions. ${ }^{122}$ Disability rights advocates saw "little downside to excluding those, since neither homosexuality nor bisexuality was considered a mental impairment under the DSM-III-R (and, therefore, was not a disability to begin with)."123 Consistent with Harkin's response to Armstrong's questions during the floor debate, "kleptomania was also included in the initial list of proposed exclusions; GID was not."124

After receiving the revised list of exclusions, Senator Hatch entered the Senate antechamber and told Feldblum and other disability rights advocates that he "needed some more." 125 Feeling "sick to her stomach," Feldblum recalls, GID and approximately six other conditions found their way onto the list - and out of the ADA. ${ }^{26}$ The final list hued closely to the floor debate: all impairments except GID and pyromania were explicitly mentioned by Senator Armstrong either on the Senate floor or in his statement published one week later. ${ }^{127}$

Well after 10 p.m. that evening, Senator Armstrong came to the floor and introduced the negotiated list as Amendment No. 722, which addressed his "most obvious concerns." 28 Senator Harkin stated that the

118. Feldblum Interview, supra note 47.

119. Id. Cf. 135 CONG. REC. S10785 (daily ed. Sep. 7, 1989) (statement of Sen. Hatch) (complimenting Senator Armstrong for "work[ing] long and hard this evening with the majority floor managers and the minority floor manager" on "a very good amendment" excluding GID and several other mental impairments, and committing to keeping amendment in final version of bill).

120. Feldblum Interview, supra note 47.

121. Id.

122. See supra notes 54-55, 58-61 and accompanying text.

123. Feldblum Interview, supra note 47.

124. Id.; see also 135. CONG. REC. S10785 (daily ed. Sep. 7, 1989).

125. Feldblum Interview, supra note 47.

126. Id.

127. 135 CONG. REC. S11175-76 (daily ed. Sep. 14, 1989) (statement of Sen. Armstrong); id. at S10754 (daily ed. Sep. 7, 1989) (statement of Sen. Armstrong).

128. 135 CONG. REC. S10785 (Sep. 7, 1989) (statement of Sen. Armstrong). See also id. at S10781 ("It is quarter of 10 at night.") (statement of Sen. Ford). 
amendment, while "narrowly focused," was something he neither wanted nor thought necessary, especially because many people with now-excluded mental impairments would not have been able to show that they "were qualified for various employment positions." 129 Senator Kennedy likewise stated that the amendment was "certainly not one that I would have wanted in the legislation," but it was one "which we can live with." 130 Senator Hatch concluded that the country would "owe [Armstrong] a debt of gratitude when this bill is implemented." 131

After passing the Senate by a vote of 76-8, the ADA was debated in the House. In the House version of the bill, disability rights advocates changed the list of excluded mental impairments slightly by subdividing the list into "Homosexuality and Bisexuality" (non-impairments) and "Certain Conditions" (impairments listed in the DSM-III-R), and deleting "psychoactive substance-induced organic mental disorders." 132 This is the language that was accepted in conference and passed into law. ${ }^{133}$

\section{The ADA as Moral Code}

Senator Armstrong wanted to exclude from the ADA nearly all mental impairments, but his legal and pragmatic reasons for doing so do not withstand scrutiny. Antidiscrimination protection for people with mental impairments is not uniquely at odds with civil rights law (the legal concern), nor would such protection necessarily lead to a flood of frivolous litigation (the pragmatic concern). ${ }^{134}$ Armstrong's moral argument against antidiscrimination protection for people with mental impairments is the only one with any traction. It comes as no surprise, then, that all ten of the mental impairments actually excluded from the ADA have, in Senator Armstrong's words, "a moral content to them." 135 With the passage of Armstrong's amendment, the ADA became, in effect, a moral code: "disability" coverage applies to those we pity, not those we despise. ${ }^{136}$

129. Id. at S10786 (statement of Sen. Harkin).

130. Id. at $S 10785$ (statement of Sen. Kennedy).

131. See id. at $\mathrm{S} 10785$ (statement of Sen. Hatch).

132. H.R. REP. No. 101-596, at 88 (1990) (Conf. Rep.).

133. 42 U.S.C. $\$ 12211$ (2006). When Congress amended the Rehabilitation Act two years later, it "add[ed] the exclusion set forth in the Americans with Disabilities Act for certain groups." H.R. REP. No. 102-973, at 158 (1992) (Conf. Rep.).

134. See supra Section III.A.3.

135. 135 CONG. REC. S10753 (daily ed. Sep. 7, 1989) (statement of Sen. Armstrong).

136. See 42 U.S.C $\$ 12211$ (2006) (excluding transsexualism and GID). Senator Alan Cranston's (D-CA) opposition to Senator Helms' amendment excluding transvestites from the Fair Housing Amendments Act proved prescient: "[T]his amendment forsakes the basic principles of fair play, reason, and justice. If we were to start excluding one category of individuals from coverage, we would be threatening to undermine the very essence of antidiscrimination laws...This amendment could open the door to any number of attempts to exclude other disabilities from this and other antidiscrimination laws... [T] he whole purpose of the Fair Housing Act and 
Professor Feldblum offers a useful framework for analyzing the various moral views that one may hold about gay people and gay sex, but this framework is equally relevant to those who are transgender. ${ }^{137}$

One possible view ... is that [being transgender] is morally harmful (and/or sinful) to the individual and to the community. Therefore, it must be discouraged to the greatest extent possible in order to advance the moral health of these individuals and of the communities in which they reside. The second view is that ... [being transgender] is not good, but it is not inherently harmful; it is more akin to an unfortunate, abnormal health condition that one does not wish for oneself ..., but it is not a harmful element that must be actively purged from society. The third view is that . . . [being transgender] has the same moral valence as [not being transgender] and [transgender] people are basically similar to [non-transgender] people. ${ }^{138}$

In 1989, GID was despised or, at best, misunderstood, by most. 139 Senators Armstrong and Helms, consistent with the first view, believed that GID was morally harmful, "abhorrent," and "deviant." 140 For them, GID was to be discouraged, not protected under the law. ${ }^{141}$ Senators Harkin and Kennedy took the second view, believing that GID was unfortunate and abnormal much like other impairments, but not harmful to others. ${ }^{142}$ Importantly, no one subscribed to the third view - that GID, or being transgender more generally, was "good."

In the end, GID was excluded from the ADA because several senators

other antidiscrimination laws is to provide across-the-board evenhanded protection, not to pick and choose disabilities we approve of and exclude the ones we don't. If we remove protections from one form of disability, who will be next?" 134 CONG. REC. S19726 (daily ed. Aug. 1, 1988) (statement of Sen. Cranston) (emphasis added); see also supra note 62 (only Senators Cranston and Weicker voted against Helms' Fair Housing Act amendment).

137. See Chai R. Feldblum, Moral Conflict and Liberty: Gay Rights and Religion, 72 BROOK. L. REv. 61, 69-70 (2006) [hereinafter Feldbum, Moral Conflict]; see also Chai R. Feldblum, Gay is Good: The Moral Case for Marriage Equality and More, 17 YALE J.L. \& FEMINISM 139, $140-41$ \& n.4 (2005) [hereinafter Feldblum, Gay is Good] (stating that moral argumentation in support of true equality for gay people "would be relevant to achieving true equality for transgender people as well").

138. Feldblum, Moral Conflict, supra note 137, at 69-70.

139. See e.g., Shannon Price Minter, Do Transsexuals Dream of Gay Rights? Getting Real About Transgender Inclusion, in TRANSGENDER RIGHTS supra note 2 at 146-50 (describing emergence of self-identified transgender rights movement as recent phenomenon, and noting historical misunderstanding of transgender people among lesbians and gay men); Colker, Homophobia, supra note 9, at 39 (discussing overwhelming support for Helms amendment excluding "transvestites" from protection under Fair Housing Amendments Act of 1988).

140. 135 CONG. REC. S10772 (daily ed. Sep. 7, 1989) (statement of Sen. Helms).

141. See supra Section III.A.1.

142. See supra notes $129-130$ and accompanying text. 
believed that it was not worthy of protection and, in the eleventh hour, the ADA's sponsors and disability rights advocates reluctantly agreed to sacrifice the inclusion of GID in exchange for the ADA's passage in the Senate. ${ }^{143}$ Had there been a transgender lobby at the time and had social perceptions of transgender people evolved, ${ }^{144}$ the result may well have been different, and the transgender community might have owed Armstrong far less "a debt of gratitude." 145

The ADA's exclusion of GID has a powerful symbolic impact. As one scholar recently commented, "[f]ederal law has an important expressive function, especially concerning the messages it sends about disadvantaged groups." 146 The fact that Congress went out of its way to exclude GID, along with nine mental impairments that involve some harm to oneself or others, sends a strong message: people with GID have no civil rights worthy of respect. ${ }^{147}$ Unlike homosexuality or bisexuality, GID is a mental impairment, the ADA tells us. But unlike other mental impairments, GID is dangerous, despicable, and undeserving of protection-like pedophilia, kleptomania, and pyromania. GID is not good.

143. See supra Section III.C.

144. See Dallas Denny, Transgender Communities, in TRANSGENDER RIGHTS, supra note 2 at 174, 183 (2006) (discussing rise of transgender lobby in mid-1990's, and gay, lesbian, and bisexual support for transgender rights by early 2000's); see also A Blueprint for Equality: A Federal Agenda for Transgender People, NATIONAL CENTER FOR TRANSGENDER EQUALITY 2 (March 2012), http://transequality.org/Resources/NCTE_Blueprint_for_Equality2012_FINAL.pdf ("[I]n 2003, transgender people barely had a foot in the door of the Washington offices where major federal policy decisions take place. Now we're at every relevant meeting, and our impact is felt at almost every table where our issues are discussed." ).

145. 135 CONG. REC. S10785 (daily ed. Sep. 7, 1989) (statement of Sen. Hatch).

146. Waterstone, supra note 19 , at 1122.

147. See 42 U.S.C. $\$ 12211$ (2006); see also S. Elizabeth Malloy, What Best to Protect Transsexuals from Discrimination: Using Current Legislation or Adopting a New Judicial Framework, 32 Women's Rts. L. Rep. 283, 299 (2011) ("[T]he ADA has instead served to legitimize discrimination against transsexual individuals, not only by deliberately excluding them from protection, but also by placing them in the same category as pedophiles, exhibitionists, and voyeurs."); id. at 319 (stating that exclusion of transgender people "from the ADA was effectively a codification of the legal system's hostility towards them"); Colker, Homophobia, supra note 9 at 50 (noting that " $[t]$ he language concerning transvestites and transsexualism is ... extremely derogatory" because " $[t]$ ranssexual and transvestite individuals are lumped together with individuals who have 'sexual behavior disorders'"); Adrienne L. Hiegel, Note, Sexual Exclusions: The Americans with Disabilities Act as Moral Code, 94 Colum. L. Rev. 1451, 1479 (1994) ("[T]he result of the ADA's exclusion is not merely to allow private employers to take action against an employee because of that employee's sexual behavior, but to do so with the state's blessing . . . perpetuat[ing] the material, tangible discrimination against sexual minorities."); see also Pamela S. Karlan, Equal Protection, Due Process, and the Stereoscopic Fourteenth Amendment, 33 MCGEORGE L. REV. 473, 485 (2002) ("The decision to exclude compulsive gamblers, kleptomaniacs, and pyromaniacs from the protections others enjoy surely reflects the majority's dislike of these politically unpopular groups."). 


\section{GENDER IDENTITY DISORDER AND THE ADA AMENDMENTS ACT OF 2008:}

\section{DISABILITYQUEER}

\section{A. New Scope of Coverage}

For nearly twenty years, the ADA was widely understood by courts and society at large to protect a narrow class of people: "those" people with impairments that impose severe functional limitations. ${ }^{148}$ Two Supreme Court decisions were largely to blame for this development. First, in 1999, in the case of Sutton v. United Airlines (and its two companion cases), the Supreme Court held that the ameliorative effects of medication and other measures must be considered in determining whether a person is disabled under the ADA. ${ }^{149}$ As a result of Sutton, many people who experienced discrimination because of an impairment were nevertheless unprotected by the ADA because their impairments did not rise to the level of a "disability" after taking into account ameliorative measures. ${ }^{150}$

Second, in 2002, in the case of Toyota Motor Manufacturing, Kentucky, Inc. v. Williams, the Supreme Court held that the words "substantially limits" and "major life activities" in the definition of disability "need to be interpreted strictly to create a demanding standard for qualifying as disabled." In order to qualify as a "disability," the Court stated, the impairment must therefore "prevent[] or severely restrict[]" life functions. ${ }^{151}$ These strict interpretations effectively gutted the ADA, "narrow[ing] the broad scope of protection intended to be afforded by the ADA, thus eliminating protection for many individuals whom Congress intended to protect." 152

In 2008, Congress responded to these decisions by passing the ADA

148. See Barry, Toward Universalism, supra note 1 , at 250.

149. See Sutton v. United Air Lines, Inc., 527 U.S. 471, 488-89 (1999); see also Murphy v. United Parcel Serv., Inc., 527 U.S. 516 (1999); Albertson's, Inc. v. Kirkingburg, 527 U.S. 555 (1999).

150. See Barry, Congress Intended, supra note 25 ("In the wake of Sutton, lower court decisions struck down the claims of an electrician with muscular dystrophy whose conditional job offer was revoked, in part, because he needed to use a ladder to reach items above his head, a pharmacist who was denied a half-hour uninterrupted lunch break to manage his diabetes, and a law enforcement officer who was fired after an examining physician determined that his depression disqualified him from his job. ... The Supreme Court had, in effect, created a tragic paradox: the better you manage your medical condition, the less likely you are to be protected from discrimination based on that condition.").

151. Toyota Motor Mfg., Ky., Inc. v. Williams, 534 U.S. 184, 187-89, 197-98 (2002), superseded by statute ADA Amendments Act of 2008, Pub. L. No. 110-325, 122 Stat. 3553, 3554 [hereinafter ADAAA]; see Barry, Congress Intended, supra note 25 ('Given this 'demanding standard,' lower courts ruled against people with a wide range of impairments, including a woman with an amputated arm, a man with a traumatic brain injury, a woman with stage III breast cancer, and a young man with intellectual disabilities.").

152. ADA Amendments Act of 2008 § 2(a)(2), 42 U.S.C. $\$ 12101$ Historical and Statutory Notes; see also id. at $\S 2(a)(5)$. 
Amendments Act, "an attack on everything the Supreme Court and lower courts had relied upon to unduly narrow the definition of disability." 153 Through the Amendments, particularly the new-and-improved "regardedas" prong, Congress clarified that, with a few exceptions, anyone discriminated against (e.g., fired, not hired) based on an impairment is protected by the ADA. ${ }^{154}$ It does not matter if the person's impairment is episodic, mitigated by medication, not functionally limiting, or even non-existent. ${ }^{155}$ In each case, that person is covered so long as an impairment (whether real or perceived) was the reason for the discrimination. ${ }^{156}$ Because everyone has an impairment of one sort or another (or may be perceived as having one), this means that everyone, with only a few exceptions, is entitled to legal protection. ${ }^{157}$ Where the denial of a reasonable accommodation is at issue, a person must show some limitation of a bodily function or life activity, but the Amendments make clear that this showing is not a demanding one. ${ }^{158}$

As a result of these changes, ADA protection is now nearly universal or, one might say, "disabilityqueer."159 The ADA does not protect "those" people with stigmatized impairments that impose severe functional limitations; it protects all of us who are treated unfairly based on impairment, whether or not our impairments are typically thought of as "disabilities." 160

153. Barry, Congress Intended, supra note 25.

154. See 42 U.S.C. $\$ 12102(3)$ (A) (2009) ("An individual meets the requirement of "being regarded as having such an impairment' if the individual establishes that he or she has been subjected to an action prohibited under this Act because of an actual or perceived physical or mental impairment whether or not the impairment limits or is perceived to limit a major life activity."); id. at $\$ 12102(3)(B)$ (exception for "transitory and minor" impairments); id. at $\S$ 12201(h) (exception for failure-to-accommodate cases).

155. See 42 U.S.C. \$ 12102(3)(A) (2009) (stating that person is covered under "regarded as" prong of definition of disability even if impairment does not substantially limit or is "perceived," not "actual"); id. at (4)(D) (requiring that episodic impairments and impairments in remission be considered in their active states); $i d$. at (4)(E) (prohibiting consideration of most mitigating measures); see also 29 C.F.R. $\$ \S 1630.2(j)(1)(v i)$ (2012) (discussing "regarded as" prong).

156. See 42 U.S.C. $\$ 12102(3)$ (A) (2009); see also Barry, Toward Universalism, supra note 1, at 208 (discussing breadth of regarded-as prong under ADA Amendments Act).

157. See Barry, Toward Universalism, supra note 1, at 278-79. The Amendments' reconstituted regarded-as prong, in effect, converts the Americans with Disabilities Act into the Americans with Impairments Act by "protect[ing] nearly anyone who is adversely treated based on any impairment - whether the impairment is actual or perceived, and functionally limiting or not." Barry, Congress Intended, supra note 25; see also Michelle A. Travis, Impairment as Protected Status: A New Universality for Disability Rights, 46 GA. L. REV. 937, 984 (2012) ("[T]he ADAAA's 'regarded as' prong now prohibits nearly all forms of impairment-based discrimination.").

158. ADAAA $\S 2(b)(5)$ ("[T]he question of whether an individual's impairment is a disability under the ADA should not demand extensive analysis.").

159. See Barry, Toward Universalism, supra note 1 , at 208 ; see also supra note 16 and accompanying text.

160. See id. at 278-79, 282; see also GLAD, TRANSGENDER LEGAL ISSUES, NEW ENGLAND 5 (2011), www.glad.org/uploads/docs/publications/trans-legal-issues.pdf (stating that " $t$ ]he term 'disability' in anti-discrimination laws ... is not used in the popular or colloquial sense, and is not limited to individuals who are significantly debilitated or who appear outwardly ill."). 
The newly amended ADA underscores that disability is not something wrong with some of us -it is something wrong with the way society may treat any of us. ${ }^{161}$

Take autism, for example. The autism spectrum is immensely broad and includes those with "severe to profound intellectual disabilities" as well as those "who are gifted and more competent than most in the community."162 All that an autistic person need show in order to be protected under the ADA is that he or she was discriminated against based on autism. ${ }^{163}$ If the person is denied a reasonable accommodation based on autism, the requisite showing is slightly different, but straightforward. ${ }^{164}$ In that case, the person must show that autism substantially limits a major bodily function (like neurological or brain function) or a major life activity (like thinking, concentrating, or social interaction). ${ }^{165}$ According to Congress, this should not be difficult to do. 166 In fact, according to the EEOC, the agency charged with enforcing the ADA's employment provisions, autism is now presumptively covered, as are major depressive disorder, PTSD, obsessive compulsive disorder, and schizophrenia. ${ }^{167}$

Given autism's wide spectrum, the EEOC's presumptive protection of autism underscores the ADA's broad scope of coverage. ${ }^{168}$ So far as the EEOC is concerned, the ADA now covers not only the non-verbal eighteenyear-old who exhibits self-injurious behavior, but also the socially awkward professor not hired for a job. ${ }^{169}$ It covers the person who views autism as a

161. See id.

162. Kevin Barry, Gray Matters: Autism, Impairment, and the End of Binaries, 49 SAN DIEGO L. REv. 161, 169 (2012) (quoting Dr. Ami Klin). "Although the DSM-IV tries to distinguish various points along the autism spectrum by providing diagnostic categories for various subtypes of autism, such as Asperger's and PDD-NOS," the DSM-5 does away with subtypes in favor of a single diagnosis: "Autism Spectrum Disorder." Id. at 170; see Autism Spectrum Disorder: Proposed Revision, AM. PSYCHIATRIC ASS'N DSM-5 DEV. Proposed revisions are no longer available online, but are on file with the author. Please see dsm5.org for the final version of the rule [hereinafter Autism Spectrum Disorder, DSM-5 Proposed Revision].

163. See 42 U.S.C. $\$ 12102(3)$ (A) (2009) ("regarded as" prong).

164. See id. $\S 12201(\mathrm{~h})$ (requiring that, when alleging failure to accommodate or to make modifications to policies, practices, or procedures, plaintiffs show they actually are or were substantially limited in a major life activity).

165. See id. \& 12102(2) (defining "major life activity" to include "concentrating" and "thinking" as well as "the operation of a major bodily function" such as "neurological" and "brain" functions); 29 C.F.R. $\$ 1630.2$ (i)(1) (2011) (stating that "[m]ajor life activities include, but are not limited to ... interacting with others ...").

166. See ADAAA § $2(\mathrm{~b})(5)$.

167. See 29 C.F.R. $\S 1630.2$ (j)(3)(iii) (2011) ("[I]t should easily be concluded that the following types of impairments will, at a minimum, substantially limit the major life activities indicated: . . . autism substantially limits brain function . . . major depressive disorder, bipolar disorder, post-traumatic stress disorder, obsessive compulsive disorder, and schizophrenia substantially limit brain function.").

168. See id.

169. See supra note 160 and accompanying text (discussing autism's variability); cf. U.S. EQUAL EMP. OPPORTUNITY COM'N Press Release: Comfort Suites To Pay $\$ 132,500$ For Disability Discrimination Against Clerk With Autism (Nov. 7, 2011), http://www.eeoc.gov/eeoc/ 
pathology in need of cure as well as the person who views autism as a form of "neurodiversity" and therefore a difference to be celebrated. ${ }^{170}$

\section{Same Moral Code}

In 2008, Congress revisited the ADA and, in striking fashion, remedied a host of problems with the ADA's definition of disability. ${ }^{171}$ But it did not remedy all of them. When given the chance to do away with the GID exclusion in 2008, Congress chose not to act-despite the presence of a national transgender lobby calling for an end to the exclusion, ${ }^{172}$ despite a wave of legal changes acknowledging the injustices faced by transgender people, ${ }^{173}$ despite refinement of the definition of GID under the DSM, ${ }^{174}$ and despite a burgeoning social and political movement dedicated to helping transgender people live in the world. ${ }^{175}$

The reason that the ADAAA did not eliminate the GID exclusion is straightforward, albeit unsatisfying. Political support for the ADAAA (originally, the "ADA Restoration Act") depended on the bill's restoring not expanding - congressional intent. ${ }^{176}$ Because Congress clearly intended

newsroom/release/11-7-11a.cfm (discussing settlement of lawsuit against hotel operator who refused to allow autistic hotel clerk assistance of job coach and subsequently fired clerk); SIMON BARON-COHEN, THE EsSENTIAL DifFERENCE: THE Truth AbOUT THE MALE ANd Female BRAIN 163-64 (2003) (discussing award-winning professor of mathematics who is autistic).

170. See Barry, Gray Matters, supra note 162, at 186 ("The neurodiversity movement originated in the 1990s in response to the dominant conception of autism as a disorder and consists primarily of generally high-functioning autistic adults and their families. . . . [T]he neurodiversity movement's central claim is that autism is not a disorder but a way of being or, more specifically, a 'different' way of being, of thinking, of behaving.").

171. See ADAAA $\S 4$.

172. See Discrimination, NATIONAL CENTER FOR TRANSGENDER EQUALITY, http://transequality.org/Issues/discrimination.htm (last visited Dec. 11, 2012) ("In order to make federal law consistent with the Employment Non-Discrimination Act [bill], Congress should alter or remove problematic language regarding transgender individuals in the Americans with Disabilities Act and related federal agency regulations."); cf. GLAD, supra note 160, at 8 ("State disability anti-discrimination laws present an important tool to eradicate irrational discrimination against transgender people in employment, housing, public accommodations and other areas of law.").

173. See, e.g., Matthew Shepard and James Byrd, Jr. Hate Crimes Prevention Act, Pub. L. No. 111-84, \$4707, 123 Stat. 2838, 2839 (2009) (extending federal hate crimes protection to, among other things, "gender identity"); Media Note, Office of the Spokesman, U.S. Dept. of State, New Policy on Gender Change in Passports Announced (June 9, 2010), http://www.state.gov/r/pa/prs/ps/2010/06/142922.htm (stating that "[s]exual reassignment surgery is no longer a prerequisite" for issuance of U.S. passport"); see also infra notes 202-06 and accompanying text (discussing passage of state laws explicitly protecting people from discrimination based on "gender identity" and federal court decisions protecting transgender people under Title VII).

174. Compare DSM-IV-TR, supra note 34, at 576-82, with DSM-III-R, supra note 34, at 71-77.

175. See Denny, supra note 144 , at $182-83$ (discussing transgender political activism and appearance of transgender voices in books and films).

176. In this way, the ADA Amendments Act is like any other congressional override, the purpose of which is to reject judicial interpretations of statutes deemed inconsistent with con- 
to exclude GID (and Transsexualism) from protection when it passed the ADA in 1990, it would not have been a "restoration" to include those conditions in 2008-it would have been an expansion. Disability rights advocates therefore made the strategic decision to leave for another day the problem of the ADA's exclusion of these impairments (and several other problems with the ADA). ${ }^{177}$

Notwithstanding these political realities, Congress's refusal to address the ADA's blanket exclusion of those with GID is deeply troubling. The continued exclusion of GID flies in the face of the ADAAA's primary purpose, which is to "reinstat[e] a broad scope of protection ... available under the ADA." 178 Through its new-and-improved "regarded as" prong, the amended ADA extends antidiscrimination protection to any individual discriminated against based on any impairment unless the impairment is "transitory and minor" or is one of those listed alongside GID. ${ }^{179}$ While it arguably made sense for Congress to continue to exclude certain impairments that necessarily involve harm to oneself or others (such as exhibitionism, compulsive gambling, pyromania, and kleptomania), ${ }^{180}$ and for Congress to guard against a flood of potentially frivolous claims by excluding "transitory and minor" impairments, 181 the continued exclusion of GID is nonsensical, offensive, and stigmatizing. ${ }^{182}$ GID has as little to do with pedophilia as it does with the common cold, and should be covered by the ADA.

gressional intent. See, e.g., Lilly Ledbetter Fair Pay Act of 2009, Pub. L. No. 111-2 § 181, 123 Stat. 5 (overriding Ledbetter v. Goodyear Tire \& Rubber Co., 550 U.S. 618 (2007)); ADAAA (overriding Toyota Motor Manufacturing, Kentucky, Inc. v. Williams, 534 U.S. 184 (2002) and Sutton v. United Air Lines, Inc., 527 U.S. 471 (1999)); Civil Rights Act of 1991, Pub. L. No. $102-$ 166, 105 Stat. 1071 (1991) (overriding six Supreme Court decisions); Civil Rights Restoration Act of 1987, Pub. L. No. 100-259, 102 Stat. 28 (1988) (overriding Grove City v. Bell, 465 U.S. 555 (1984)); Rehabilitation Act Amendments of 1986, Pub. L. No. 99-506, 100 Stat. 1807 (overriding Atascadero State Hosp. v. Scanlon, 473 U.S. 234 (1985)); Air Carrier Access Act of 1986, Pub. L. No. 99-435, 100 Stat. 1080 (overriding United States Dep't of Transp. v. Paralyzed Veterans of Am., 477 U.S. 597 (1986)); Handicapped Children's Protection Act of 1986, Pub. L. No. 99-372, 100 Stat. 796 (overriding Smith v. Robinson, 468 U.S. 992 (1984)); see generally William N. Eskeridge, Jr., Overriding Supreme Court, 101 YALE L.J. 331, 332 \& n.1 (1991) (discussing congressional overrides of Supreme Court statutory interpretation decisions).

177. See Kevin Barry, Personal Notes on ADA Amendments Act Advocacy Effort; see also Barry, Toward Universalism, supra note 1, at $251 \mathrm{n} .292$ ("Given the political difficulties associated with a broad legislative fix, disability rights advocates determined early on that the ADA restoration effort ought to focus on what they believed was the biggest problem - the ADA's scope of coverage.").

178. ADAAA § 2(b)(1), 42 U.S.C. § 12101 Historical and Statutory Notes; see also 42 U.S.C. § 12102(4)(A) ("The definition of disability in this Act shall be construed in favor of broad coverage of individuals under this Act, to the maximum extent permitted by the terms of this Act.").

179. 42 U.S.C. $\$ 12102(3)$ (A) (2009) (“regarded as" prong); id. at \$ 12102(3)(B) (exception for "transitory and minor" impairments); id. at \$ 12211(b) (exception for GID and certain other mental impairments).

180. See DSM-IV, supra note 34, at 525-26, 612-15.

181. See Barry, Toward Universalism, supra note 1 , at $273 \&$ n.410.

182. See supra note 145 and accompanying text. 
Sometimes laws create the very thing they seek to dismantle. ${ }^{183}$ The 2008 amendments to the ADA demonstrate the law's power to redress disadvantage by expanding protection for those treated unfairly based on their impairments. At the same time, Congress's continued exclusion of GID from protection under the ADA demonstrates the law's power to entrench the disadvantage of people with GID. By refusing to cover GID, the ADA's message to people with GID, and to the transgender community more broadly, is now clearer than ever: nearly twenty years after the passage of the ADA, they still have no civil rights worthy of respect. People with GID are still despicable and even dangerous, and therefore undeserving of legal protection under federal disability law. ${ }^{184}$ The ADA's moral code remains, with GID retaining its last-place position in the hierarchy of mental impairments.

\section{Federal PROTECTION FOR TRANSGENDER PEOPLE: THE "ADA INCLUSION $\mathrm{ACT}^{\prime \prime}$}

The ADA's exclusion of GID in 1990 was based on nothing more than the moral opprobrium of a small handful of senators, conveyed in the eleventh hour of a marathon floor debate and in the absence of an organized transgender lobby. ${ }^{185}$ In 2008, when Congress decided to expand the $\mathrm{ADA}^{\prime}$ 's definition of "disability" to protect more people, 186 things should have been different for people with GID. Sadly, they were not. Instead of removing the GID exclusion once and for all, Congress enshrined its moral opposition toward people with GID by preserving the exclusion.

This should trouble those who seek true equality for transgender people. While Congress's decision not to revisit the GID exclusion was understandable as a matter of politics, it was wrong as a matter of morality -a set-back for the project of making transgender "good." 187 The ADA should be righted again through passage of a modest bill, the "ADA Inclusion Act," which deletes the words "gender identity disorders not resulting from physical impairments" and "transsexualism" from the ADA's list of excluded impairments. ${ }^{188}$

183. See Claire H. Liachowitz, Disability as a SOCIAL CONSTRuCt 107 (1988) (discussing how laws "help to create disability").

184. See Levi \& Klein, supra note 35, at 75 ("At the heart of the federal exclusion of transgender people from the ADA lies bias, bigotry, and misunderstanding of transgender people.").

185. See supra Section III.B.

186. See ADAAA $\$ 4$.

187. See supra note 138 and accompanying text.

188. This Article does not argue that "transvestism" should be deleted from the ADA's list of excluded impairments. As discussed above, the impairments excluded from the ADA derive from the DSM. See supra notes 118-19 and accompanying text. According to the DSM, "Transvestism" (renamed "Transvestic Fetishism" under the DSM-III-R (1987) and, under the proposed DSM-5, now called "Transvestic Disorder") is highly specific-it refers to sexual 
An "ADA Inclusion Act" would no doubt face objections for a variety of reasons and from a variety of constituencies, including the religious community. ${ }^{189}$ But the most salient objections would likely come from those with a personal stake in a GID diagnosis, from members of the transgender community "whose gender identity or expression does not conform to the social expectations for their assigned sex at birth." 190

Importantly, the transgender community is not a monolith. It includes "transsexual" people who have undergone hormonal treatment or surgery in order to align their anatomy and gender identity, people "who undergo

arousal from cross-dressing that results in significant distress or impairment. See Transvestic Disorder: Proposed Revision, AM. PsYCHIATRIC ASs'N DSM-5 DEV. Proposed revisions are no longer available online, but are on file with the author. Please see dsm5.org for the final version of the rule; see also Ray Blanchard, The DSM Diagnostic Criteria for Transvestic Fetishism, available at http://www.dsm5.org/Documents/Sex\%20and\%20GID\%20Lit\%20Reviews/

Paraphilias/DSMV.TF.pdf (discussing changes to "Transvestism" in successive versions of DSM). Importantly, "Transvestism" does not refer more broadly to cross-dressing absent sexual arousal and distress, nor does it refer to GID. DSM-IV, supra note 34, at 536-37. Therefore, while those with Transvestic Fetishism would continue to be excluded under the ADA, the "ADA Inclusion Act" would likely protect cross-dressers (under the "regarded-as" prong, 42 U.S.C. § 12102(3)(A) (2006)) and, of course, people with GID.

One might argue that Transvestic Fetishism should not be excluded from protection under the ADA because, unlike other sexual disorders such as voyeurism and pedophilia, it does not involve either "the suffering or humiliation of oneself or one's partner" or "children or other nonconsenting persons." See DSM-IV, supra note 34, at 522-23. Alternatively, one might argue that Transvestic Fetishism should not be excluded because no sexual disorder should be excluded, given that the ADA already provides a "safety valve" that allows employers and businesses to discriminate against people who pose a "direct threat" to the health or safety of others, see 42 U.S.C. $\$ 12113(\mathrm{~b})$ (2006), and given that the exclusion unfairly deprives protection to those who are "recovered" or are falsely perceived as having a sexual disorder (under the "regarded-as" prong), see id. \$12102(3)(A). These arguments have much merit. Nevertheless, because "Transvestic Fetishism" is a "sexual disorder" under the DSM - as opposed to GID (and Transsexualism), which is not-an argument for inclusion of Transvestic Fetishism implicates the inclusion of other sexual disorders and, potentially, all of the remaining impairments excluded from the ADA. To avoid conflating support for inclusion of GID with support for inclusion of all sexual disorders, psychoactive substance abuse disorders, and certain impulsecontrol disorders, the "ADA Inclusion Act" should target the "low-hanging fruit" and seek inclusion of GID (and Transsexualism) only.

189. See, e.g., Employment Non-Discrimination Act of 2009: Hearing on H.R. 3017 Before the H. Comm. on Educ. and Labor, 111th Cong. 5 (2009) (written testimony of Craig L. Parshall, Senior Vice-President and Gen'l Counsel, Nat'l Religious Broadcasters), available at http://democrats.edworkforce.house.gov/sites/democrats.edworkforce.house.gov/files/doc uments/111/pdf/testimony/20090923CraigParshallTestimony.pdf ("Neither the Congress nor the courts have jurisdiction over the religious beliefs of people of faith.... Christian ministries that object to those sexual preferences which are in clear violation of the standards of the Bible are standing on a long and well-worn road."); see also 134 CONG. REC. 54236 (daily ed. Mar. 17, 1988) supra note 62 (statement of Sen. Helms). Religious arguments against GID inclusion ought to have less force, especially in the employment context, given the ADA's explicit exemption for religious entities, see 42 U.S.C. $\$ \$ 12113(d), 12187$, and the Supreme Court's recognition of the ministerial exception in Hosanna-Tabor Evangelical Lutheran Church and Sch. v. E.E.O.C., 132 S. Ct. 694, 697 (2012), which bars the application of employment discrimination laws to the "employment relationship between a religious institution and its ministers" under the First Amendment. Id.

190. Currah et al., supra note 2 , at xiv. 
no medical treatment but also take steps to conform their gender expressions to meet their gender identities," 191 and the "Genderqueer" -i.e., those who "redefine[] or play[] with gender, or who refuse[] gender altogether"; those "who bend/break the rules of gender and blur the boundaries"192 and "live outside of the gender norms of society."193

Given the diversity of the transgender community, transgender attitudes toward GID are wide-ranging. Some transgender people, for example, regard the misalignment of their anatomy and gender identity as a mental impairment and accept the GID diagnosis. ${ }^{194}$ Others attribute this misalignment to differences in the brain or central nervous system and therefore believe it to be a physical impairment. ${ }^{195}$ Still others reject the notion of "impairment" altogether and argue instead for an understanding of gender nonconformity as "a practice of self-determination, an exercise of autonomy. ... one among many human possibilities of determining one's gender for oneself."196 Echoing autism's neurodiversity movement, this thread of the transgender community acknowledges the discomfort experienced by transgender people, but attributes the discomfort to "something caused purely by cultural prejudices rooted in gender stereotypes" - not pathology. 197 Some have even called for elimination of the GID diagnosis altogether. ${ }^{198}$

While some members of the transgender community explicitly support

191. Levi \& Klein, supra note 35 , at 80 . Not all those who take steps to conform their gender expressions to meet their gender identities identify as transgender; some "identify simply as men and women." U.S. Office of Pers. Mgmt., Guidance Regarding the Employment of Transgender Individuals in the Federal Workplace (May 27, 2011), http://www.opm.gov/ diversity/Transgender/Guidance.asp.

192. LGBT Resources-Definition of Terms, GENDER EQUITY RESOURCE CENTER, http://geneq.berkeley.edu/lgbt_resources_definiton_of_terms\#gender_queer.

193. Teaching Transgender, supra note 34 , at 17.

194. See Levi \& Klein, supra note 35, at 80-81.

195. See id. at $81,84-85$.

196. See Butler, Undiagnosing Gender, supra note 13, at 275.

197. See Levi \& Klein, supra note 35, at 81.

198. See Butler, Undiagnosing Gender, supra note 13, at 275 (stating that "some activist psychiatrists and trans people have argued that [GID] should be eliminated altogether"); see also Denny, supra note 144, at 184(stating that "many transsexuals reject the medical model of transsexualism" that "view[s] them as mentally ill"); Hébert, supra note 14, at 541 n.30 ("[P]ortions of the transgender community object to the inclusion of gender identity disorder in the DSM-IV-TR precisely because of the resulting categorization of gender identity disorder as a mental illness and the resulting stigmatization."); GID (Adult), GID REFORM ADVOCATES, www.gidreform.org/gid30285.html (advocating reform of GID diagnosis on grounds that it "serves to confuse cultural nonconformity with mental illness and pathologize ordinary behaviors as symptomatic."); id. at www.gidreform.org ("It is time for the medical professionals to affirm that difference is not disease, nonconformity is not pathology, and uniqueness is not illness."); SHANNON MiNTER \& PHYllis RANDOLPH FRYE, GID AND THE TRANSGENDER MOVEMENT: A JOINT STATEMENT BY THE INTERNATIONAL CONFERENCE ON TRANSGENDER LAW AND EMPLOYMENT POLICY (ICTLEP) AND THE NATIONAL CENTER FOR LESBIAN RIGHTS (NCLR) (Nov. 14, 1996) [hereinafter JOINT STATEMENT], http://www.transgenderlegal.com/gid1.htm (arguing that "transsexualism should become a medical rather than a psychiatric status."). 
GID's inclusion under the ADA, not all do. ${ }^{199}$ For this thread of the transgender community, the ADA Inclusion Act may be controversial for a number of reasons.

\section{A. "Disability Rights Protection is Infeasible and Unnecessary"}

The most obvious objection is political: Congress is unlikely to revisit a statute that they amended less than four years ago. This is especially true given the direction of transgender policy in recent years, and even in recent months, which points toward legal protections based on "sex" and "gender identity" - not disability. ${ }^{200}$ In the wake of the Supreme Court's decision in Price Waterhouse v. Hopkins, which held that Title VII's prohibition on "sex" discrimination in the workplace extends to discrimination based on sex stereotypes, ${ }^{201}$ a growing number of federal circuit and district courts have held that Title VII protects transgender people based on their failure to ad-

199. Compare supra note 172 and accompanying text, with Jeannie J. Chung, Identity or Condition?: The Theory and Practice of Applying State Disability Laws to Transgender Individuals, 21 COLUM. J. GENDER \& L. 1, 35-36 (2011) ("[I]t is highly likely that using disability laws will perpetuate the medicalization of transgender individuals, that is, transgender individuals' continued reliance on the medical profession to obtain legal entitlements and protections on the basis of their transgender status. . . . For this reason, disability anti-discrimination laws, with their current emphasis on the medical model of disability, may do more harm than good for transgender individuals."); id. at 36 (stating that application of state disability law to transgender people "may further the pathologization of transgender individuals, since the DSM-IV defines GID as a mental illness"), Malloy, supra note 147, at 300 ("Perhaps the most controversial issue within the transsexual community with respect to disability antidiscrimination laws concerns whether they should be considered disabled at all."), Rose, supra note 9, at 436 n. 199 (noting lack of consensus "even among transsexuals, as to whether [transsexualism] should be classified as a disability"), MINTER \& FRYE, JOINT STATEMENT, supra note 198 (stating that "the disability rights model is [n]either the only [n]or the most effective way to win civil rights protections for transgendered people," and that it "perpetuat[es] ... the stereotype that transgendered people are inherently disturbed or unstable"), and supra note 198 and accompanying text.

200. Even assuming the political stars aligned in such a way as to allow for further amendment of the ADA, many in the disability rights community might reasonably resist such amendment for fear of opening the ADA to amendments that would make it more difficult for people to assert their rights under the statute. One such proposed amendment would likely be the ADA Notification Act, which has been introduced in seven consecutive Congresses. The ADA Notification Act of 2011, H.R. 881, 112th Cong. $\$ 2$ (2011). This bill would prohibit a state or federal court from exercising jurisdiction over an ADA Title III (public accommodations) suit unless "the plaintiff provides the defendant with a written notice of . . the facts that constitute the alleged violation" by registered mail, and ninety days (which may be extended up to 120 days) elapses without the defendant correcting the alleged violation. Id.; see generally Samuel R. Bagenstos, The Perversity of Limited Civil Rights Remedies: The Case of "Abusive" ADA Litigation, 54 UCLA L. REv. 1, 17 (2006) (discussing ADA Notification Act).

201. See 490 U.S. 228, 251 (1989) ("[W]e are beyond the day when an employer could evaluate employees by assuming or insisting that they matched the stereotype associated with their group, for in forbidding to discriminate against individuals because of their sex, Congress intended to strike at the entire spectrum of disparate treatment of men and women resulting from sex stereotypes."). 
here to the stereotypes associated with their assigned sex at birth. ${ }^{202}$ On April 20, 2012, the EEOC issued a groundbreaking decision adopting the reasoning of these courts and holding that "claims of discrimination based on transgender status, also referred to as claims of discrimination based on gender identity, are cognizable under Title VII's sex discrimination prohibition." 203 Title VII coverage for transgender people is now the official position of the federal government.

Furthermore, sixteen states plus the District of Columbia, as well as over 150 cities and counties, have passed laws prohibiting discrimination based on gender identity. ${ }^{204}$ And proposed federal legislation awaits. Since 2007, the Employment Nondiscrimination Act (ENDA), a bill intended to prohibit employment discrimination based on "sexual orientation" and "gender identity," has been introduced in Congress. ${ }^{205}$ Given these channels of existing and potential legal protection, one might argue, the transgender community does not need disability rights law. There are two responses to

202. See Ann C. Mcginley, Erasing Boundaries: Masculinities, Sexual Minorities, and Employment Discrimination, 43 U. MICH. J.L. REFORM 713, $751-57$ (2010) (discussing federal appeals court decisions in which transgender workers were covered under Title VII). While a growing number of courts have concluded that, under Price Waterhouse v. Hopkins, Title VII prohibits discrimination against transgender people based on their failure to comply with sex stereotypes, courts almost universally agree that Title VII does not prohibit discrimination based on an individual's transgender status alone. See id. at 732, 750. But see Schroer v. Billington, $577 \mathrm{~F}$. Supp. 2d 293, 306-07 (D.D.C. 2008) (holding that employer's refusal to hire person because she was transsexual was "because of sex" and therefore prohibited under Title VII); see also Macy, EEOC Appeal No. 0120120821, 2012 WL 1435995 (April 20, 2012) ("Although most courts have found protection for transgender people under Title VII under a theory of gender stereotyping, evidence of gender stereotyping is simply one means of proving sex discrimination. ... [W]e conclude that intentional discrimination against a transgender individual because that person is transgender is, by definition, discrimination 'based on . . . sex,' and such discrimination therefore violates Title VII.") (emphasis added).

203. Macy, EEOC Appeal No. 0120120821, 2012 WL 1435995 (April 20, 2012).

204. See Know Your Rights: Employment Discrimination and Transgender People, NATIONAL CENTER FOR TRANSGENDER EQUALITY 1 (May 2012), http://transequality.org/Resources/

EmploymentKnowYourRights_May2012.pdf. On July 6, 2011, Connecticut became the fifteenth state to prohibit discrimination based on gender identity. Nan Hunter, Connecticut becomes 15th state to prohibit anti-trans discrimination, HUNTER OF JUSTICE BLOG (July 6, 2011), http://hunterofjustice.com/2011/07/15th-state.html. Interestingly, while law student support for the bill was strong, it was not universal. Compare An Act Concerning Discrimination: Hearing on H.B. 6599 Before the J. Comm. on the Judiciary, 2011 Leg., Reg. Sess. (Conn. 2011) (testimony of Ted Rucci, third-year law student, Quinnipiac University School of Law, On Behalf of Quinnipiac University School of Law Q Alliance, Yale Law School Outlaws, and UConn Law School Lambda Law Society (testifying in support of transgender civil rights bill on behalf of all three of Connecticut's LGBT law student organizations), with An Act Concerning Discrimination: Hearing on H.B. 6599 Before the J. Comm. on the Judiciary, 2011 Leg., Reg. Sess. (Conn. 2011) (testimony of James Bailey Brislin, second-year law student, Western New England College School of Law) (testifying in opposition).

205. See, e.g., Employment Non-Discrimination Act of 2011, H.R. 1397, 112th Cong. (2011); see also Employment, Non-Discrimination Act: Legislative Timeline, HUMAN RigHTS CAMPAIGN, www.hrc.org/resources/entry/employment-non-discrimination-act-legislative-timeline (tracing history of ENDA bill from 1994 ["sexual orientation" only] to present [including "gender identity"]). 
this objection.

\section{The More Rights the Better}

The first is straightforward: current antidiscrimination protection for transgender people on the basis of "sex" and "gender identity" is precarious at best. While both the EEOC and many courts have interpreted Price Waterhouse to prohibit discrimination against transgender people under Title VII ${ }^{206}$ successfully making out a case of gender stereotyping is no easy feat, especially where the case involves restroom usage or dressing and grooming standards. ${ }^{207}$ The ADA, by contrast, is well-suited to combat discrimination against transgender people. 208 Unlike Title VII, the ADA explicitly defines discrimination to include the failure of an employer to "mak[e] reasonable accommodations to the known physical or mental limitations of an otherwise qualified individual with a disability."209 Such reasonable accommodations might include, for example, temporarily modifying policies governing restroom usage and dressing and grooming standards, as well as modifying a person's work schedule or granting a person leave to seek counseling, hormone therapy, electrolysis, reassignment surgery, or other treatment. ${ }^{210}$

206. See supra notes 202-203 and accompanying text.

207. See Mcginley, supra note 202, at 750, 757-61 (stating that while "transgender persons may enjoy partial coverage [under Title VII] . . . their method of proof is difficult and their efforts are often unsuccessful" and noting cases in which courts ruled against transgender plaintiffs); see also Angela Clements, Sexual Orientation, Gender Nonconformity, and Trait-Based Discrimination: Cautionary Tales from Title VII \& An Argument for Inclusion, 24 BERKELEY J. GENDER L. \& JUST. 166, 180 (2009) ("The dress and grooming codes cases are the clearest example of narrow protection for gender nonconformity under Title VII.").

208. Cf. Levi \& Klein, supra note 35, at $74 \mathrm{n} .1$ (citing cases in which transgender people were protected under state disability antidiscrimination laws); accord Chung, supra note 199, at 15 n.66.

209. 42 U.S.C. § 12112(b)(5)(A) (2006) (ADA Title I); see also 28 C.F.R. $\$ 35.130(b)(7)(2012)$ ("A public entity shall make reasonable modifications in policies, practices, or procedures when the modifications are necessary to avoid discrimination on the basis of disability ...") (Department of Justice regulations implementing ADA Title II); 42 U.S.C. $\$ 12182(b)(2)(A)(i i)$ (2006) (" $[D]$ iscrimination includes ... a failure to make reasonable modifications in policies, practices, or procedures, when such modifications are necessary to afford such goods, services, facilities, privileges, advantages, or accommodations to individuals with disabilities ...") (ADA Title III). Title VII contains a modest reasonable accommodation requirement, but only for religion. 42 U.S.C. \$ 2000e(j) (2006) ("The term 'religion' includes all aspects of religious observance and practice, as well as belief, unless an employer demonstrates that he is unable to reasonably accommodate to an employee's or prospective employee's religious observance or practice without undue hardship on the conduct of the employer's business.").

210. See 42 U.S.C. \$ 12111(9)(B) (2006) (defining "reasonable accommodation" to include "job restructuring" and "part-time or modified work schedules"); 29 C.F.R. Pt. 1630 App. (2012) ("[O]ther accommodations could include permitting the use of accrued paid leave or providing additional unpaid leave for necessary treatment ..."). The question whether ADA coverage of GID would force employer-provided health insurance plans to cover sex reassignment surgery (SRS) and other medical procedures relating to gender reassignment is a fas- 
Furthermore, Title VII and the proposed ENDA (which is still a long way from passage) 211 are not comprehensive. Unlike the ADA, they do not extend beyond the workplace to all of the other places that intimately touch transgender lives: the high school and the university, the department store and the restaurant, the homeless shelter and the hotel, the adoption agency and the foster home, the hospital and the senior citizen center, the health club and the beauty shop, the bus station and the airport, the prison and the police station, the department of social services and the registry of motor vehicles. ${ }^{212}$ State law, moreover, is a patchwork quilt, with some states extending broad protection to transgender people, others extending narrow

cinating and complex one. While a fulsome discussion of this issue is beyond the scope of this Article, some brief points are in order. Generally speaking, $\$ 501(\mathrm{c})(3)$ of the ADA permits health insurance plans to make disability-based distinctions - such as the exclusion of SRS-so long as the plan is "bona fide" and its challenged disability-based distinction is not being used as a "subterfuge to evade the purposes of [the ADA]." A plan is "bona fide" if "it exists and pays benefits, and its terms have been accurately communicated to employees." THE U.S. EQUAL EMPLOYMENT OPPORTUNITY COMMISSION, NOTICE CONCERNING THE AMERICANS With DisABILITIES ACT AMENDMENTS ACT OF 2008, No. $915.002 \S$ III(C)(1) (June 8, 1993), http://www.eeoc.gov/policy/docs/health.html. A plan's disability-based distinction is not being used as a "subterfuge" if it is "justified by the risks or costs associated with the disability," for example, if the distinction: is attributable to increased risks (and thus increased cost to the health insurance plan) of the disability, and not to the disability per se"; "would have been so expensive as to cause the health insurance plan to become financially insolvent"; or would result in "a drastic increase in premium payments (or in co-payments or deductibles), or a drastic alteration to the scope of coverage or level of benefits provided . . ." Id. $\$$ III(C)(2). Although elimination of the ADA's GID exclusion would permit transgender people to challenge health insurance plans' GID-based distinctions, it is far from clear whether those challenges would be successful. See Amy Monahan \& Daniel Schwarcz, Will Employers Undermine Health Care Reform by Dumping Sick Employees?, 97 VA. L. REV. 125, 148-49 (2011) (stating that ADA gives employers "a tremendous amount of discretion in carving out entire categories of treatment, even if doing so would create disability-based distinctions, provided that such treatments are in fact high-cost and will therefore create the needed actuarial data."); Hong, supra note 46 , at 96 (stating that "[m]any private insurance companies exclude [G]RS and hormone treatments from their coverage" and "defend the exclusion clause . . a a reasonable measure to contain costs and disallow superfluous procedures," but arguing that such clauses are motivated by non-medical and non-fiscal criteria).

211. While passage of ENDA is likely inevitable, it will take some time. In 2007, the "lastminute jitters [of] some Democrats" over ENDA's trans-inclusive language prompted Members of Congress to introduce a "compromise" bill that stripped out "gender identity," fracturing the coalition of transgender and gay rights organizations in the process. A NonTransgender-Inclusive ENDA? No Way!, NATIONAL GAY AND LESBIAN TASK FORCE (Sep. 27, 2007) http://www.thetaskforce.org/press/releases/prMF_092707. Neither the trans-inclusive nor the sexual-orientation-only bill passed.

212. Compare 42 U.S.C. $\S 2000 \mathrm{e}-2$ (2006) (prohibiting discrimination in employment) and Employment Non-Discrimination Act of 2011, H.R. 1397, 112th Cong. \$ 4 (2011) (same), with Americans with Disabilities Act of 1990 \$ 101-107, 42 U.S.C. $\S \S 12111-12117$ (2006) (prohibiting discrimination in employment), id. at $\$ \$ 201-245,42$ U.S.C. $\$ \S 12131-12165$ (prohibiting discrimination in public services), and id. at $\$ \$ 301-309,42$ U.S.C. $\$ \$ 12181-12189$ (prohibiting discrimination by private entities that operate places of public accommodation). For an excellent survey of the various forms of discrimination faced by transgender people, see generally, INJUSTICE AT EVERY TURN, supra note 18. 
protection, and most extending no protection. ${ }^{213}$

ADA coverage would therefore fill important gaps and provide another, and surer, layer of needed protection. ${ }^{214}$ To the extent that some redundancies exist, overlapping protection is by no means new to antidiscrimination law and is probably a good thing. ${ }^{215}$ While the political will to further amend the ADA may be a long way off, that is no reason not to pursue it; ENDA is a case in point and well worth the wait.

\section{More than Rights: Transgender is "Good"}

Second, and more importantly, even if transgender people were to win robust legal protections through laws based on "sex" and "gender identity," they will have won only part of the battle. As Professor Feldblum argues, in order to achieve true equality for transgender people, "changing the public's perception of the morality ... of changing one's gender may ultimately be necessary... "216 Transgender advocacy should therefore seek to win more than rights to fair and equal treatment under sex and gender identity discrimination law; it should seek to win hearts by showing that transgender is "good." 217

To do this, transgender advocacy must rebut the moral case against transgender people. The ADA should play a prominent role in this project because the ADA's GID exclusion is the moral case against transgender people; it is a moral attack that likens transgender people to people with pedophilia and pyromania who are harmful to the health of the community. ${ }^{218}$ Rather than ceding the moral floor to the opponents of transgender rights, advocates should seize on the GID exclusion to affirm and advance the moral legitimacy of changing genders and otherwise defying gender norms.

Consider the testimony of Kallista H. Solyn, a transgender woman in Connecticut, who testified before Connecticut's Judiciary Committee in

213. See Scope of Explicitly Transgender-Inclusive Anti-Discrimination Laws, TRANSGENDER LAW AND POlICY INSTITUTE \& NATIONAL GAY AND LESBIAN TASK FORCE (Aug. 1, 2008), http://www.thetaskforce.org/downloads/reports/fact_sheets/TI_antidisc_laws_7_08.pdf.

214. Cf. Levi \& Klein, supra note 35 , at 75 (arguing that "transgender persons who experience discrimination in employment, housing, public accommodations, and other areas fit neatly within the definition of 'disability' used in modern civil rights laws").

215. The Rehabilitation Act and ADA, for example, target some of the same acts and actors. See Americans with Disabilities Act of $1990 \S \S 201-02,42$ U.S.C. $\S \S 12131-32$ (2006) (amended 2009) (prohibiting discrimination by state and local government); Rehabilitation Act of $1973 \S$ 504,29 U.S.C. $\$ 794$ (2006) (prohibiting discrimination by federally funded entities).

216. Feldblum, Gay is Good, supra note 137 at 141 (emphasis added).

217. See id.at 141-42 (arguing that lack of "[d]irect engagement with the issues of morality surrounding either gay sex or gender identity ... represents a serious deficiency in our articulation of the justification for LGBT equality").

218. See 42 U.S.C. $\$ 12211(b)$. 
2011 in support of a state transgender civil rights bill. ${ }^{219}$ After fourteen years of service to her employer, a privately owned aviation-related company, Ms. Solyn was terminated after informing her supervisor of her plans to undergo gender reassignment surgery. "Within several days of disclosing my intention to transition," Ms. Solyn explained, "I was asked, by the firm's owners, to 'do the right thing for the sake of the company, and resign.' I refused . . . . Being transgender is not a 'phase or a lifestyle.' I was born this way and I can no more change my gender identity than I could change the color of my skin." 220

Ms. Solyn is not sick. In fact, she is not all that different from the rest of us. She, like so many of us, wants to pursue her basic human capabilities, that is, to "live a safe, well-nourished, productive, educated, social, and politically and culturally participatory life of normal length." 221 But, unlike many of us, she cannot do so without changing her gender. While most of will not undergo hormonal and surgical procedures to transition to the opposite sex, any one of us might choose that option if we could not fulfill our basic human capabilities without doing so. One might also choose something less restrictive, "blend[ing] genders as if from a palette." 222 One might choose to "transition gender roles without a goal of genital surgery, acknowledge one's gender dysphoria and yet remain in one's original gender role, to take hormones for a while and then stop, [or] be a woman with breasts and a penis or a man with a vagina ...."223

No matter which path one chooses, nonconformance with gender norms does not destroy community-it perfects it by allowing members of the community to pursue their capabilities to the maximum extent. When viewed in this way, the moral case against transgender people, one might reasonably argue, is little more than a failure of empathy.

\section{B. “Disability Rights Protection Stigmatizes Transgender People By Labeling Them 'Disabled"'}

Even if one were to agree that transgender advocacy ought to make the moral case for transgender equality, one might reasonably argue that GID's inclusion under the ADA is not the right way to do it. Disability rights law cannot make gender nonconformity "good," the argument goes, because disability is never good. ${ }^{24}$ According to this view, disability refers to im-

219. An Act Concerning Discrimination: Hearing on H.B. 6599 Before the Judiciary Committee, 2011 Leg., Reg. Sess. (Ct. 2011) (statement of Kallista H. Solyn, constituent).

220. Id.

221. Feldblum, Gay is Good, supra note 137, at 158 n.57 (citing Robin L. West, Rights, Capabilities and the Good Society, 69 FORDHAM L. REV. 1901, 1902 (2001)).

222. Denny, supra note 144 , at 182

223. Id.

224. See Emens, supra note 16, at 227, 230 (discussing "the highly negative social status of disability" as compared with other protected classes like race or sex, and stating that 
pairments that are stigmatized - those that impose functional limitations that render people "abnormal or defective in mind or body." 225 At best, all that disability rights law can do is make transgender people the objects of pity. Rather than aid transgender people's rise from the ranks of morally harmful (the first moral view) to good (the third moral view), GID's inclusion would lock them in disability's stigmatizing limbo: those people with "unfortunate, abnormal health conditions" who are neither good nor harmful to the community (the second moral view). ${ }^{226}$

This argument ignores the impact of the ADA Amendments Act of 2008 (ADAAA), which significantly expands the ADA's definition of disability in two ways. First, in cases that do not involve a request for reasonable accommodation, the ADAAA clarifies that a person is "disabled" if the person is treated adversely because of an impairment - whether that impairment is real or perceived, and whether it actually limits major life activities or not.227 "No-one's body works perfectly, or consistently, or eternally. We are all in some way impaired." 228 Since all of us have impairments of one sort or another, ${ }^{229}$ and since any of us can be regarded as having an impairment of one sort or another, the ADA now covers all of us. ${ }^{230}$ Disability coverage is therefore not stigmatizing - at long last, it is something broadly shared. ${ }^{231}$

Second, while those seeking reasonable accommodations must still show that their impairments "substantially limit" their "major life activities," the ADAAA significantly reduces this threshold showing. ${ }^{232}$ Recent caselaw under the ADAAA tells the story: ankle injuries, ${ }^{233}$ anxiety disorder, ${ }^{234}$ back

"[d]isability is rarely understood as a positive state or identity with social or cultural benefits to its bearers or those around them").

225. See Bagenstos, supra note 26, at 437, 444 (2000) (discussing the minority group approach to disability, which locates disability in a discrete group of people whose medical impairments are "stigmatized," that is, those who "differ too much from a socially defined "norm,'" such that they are considered "abnormal or defective in mind or body.").

226. Feldblum, Moral Conflict, supra note 137, at 69-70.

227. See 42 U.S.C. $\$ 12102(3)$ (A) (2006).

228. Tom Shakespeare \& Nicholas Watson, The Social Model of Disability: An Outdated Ideology?, in 2 RES. IN SOC. SCI. \& DiSABILITY 9, 24 (Sharon N. Barnartt \& Barbara M. Altman eds., 2001).

229. See id. at 24-25 (“[T]here is no qualitative difference between disabled people and nondisabled people, because we are all impaired. Impairment is not the core component of disability ...., it is the inherent nature of humanity. For example, the Human Genome Project has shown that every individual's genome contains mutations[, such] as predispositions to late onset diseases such as cancer, heart disease and dementia .... [E]veryone has limitations, and . . . everyone is vulnerable to more limitations and will, through the ageing process, inevitably experience functional loss and morbidity.").

230. Barry, Toward Universalism, supra note 1, at 278-79.

231. See id.

232. See 42 U.S.C. $\$ 12102(4)$ (2006).

233. Fleck v. Wilmac Corp., No. 10-05562, 2011 WL 1899198, at *5-6 (E.D. Pa. 2011) (denying employer's motion to dismiss).

234. Gesegnet v. J.B. Hunt Transport, Inc., No. 3:09-CV-828-H, 2011 WL 2119248, at *4 
injuries, ${ }^{235}$ bipolar disorder, ${ }^{236}$ broken legs, ${ }^{237}$ carpal tunnel syndrome, ${ }^{238}$ depression, ${ }^{239}$ diabetes, ${ }^{240}$ eating disorders, ${ }^{241}$ gastrointestinal problems, ${ }^{242}$ insomnia, ${ }^{243}$ monocular vision, ${ }^{244}$ obesity, ${ }^{245}$ pain in the hands, joints, and hip, ${ }^{246}$ psoriatic arthritis, ${ }^{247}$ and stuttering ${ }^{248}$ can all be covered under the ADA. These are not the sort of impairments that are considered to be particularly unfortunate or abnormal, and yet the ADA considers them "disabilities" all the same. Thanks to the 2008 amendments, the ADA is now "disabilityqueer": it rightly blurs the line between the healthy "us" and the unfortunate "disabled" by focusing on how attitudes - not impairments limit people's lives. ${ }^{249}$ Because the newly amended ADA covers nearly all

(W.D. Ky. 2011) (assuming disability but granting employer's motion for summary judgment based on employee's failure to adequately request reasonable accommodation).

235. Cohen v. CHLN, Inc., No. 10-00514, 2011 WL 2713737, at *8 (E.D. Pa. 2011) (denying employer's motion for summary judgment).

236. Gesegnet, 2011 WL 2119248, at *4 (assuming disability but granting employer's motion for summary judgment based on employee's failure to adequately request reasonable accommodation).

237. Patton v. Ecardio Diagnostics LLC, 793 F. Supp. 2d 964, 968-69 (S.D. Tex. 2011) (denying employer's motion for summary judgment).

238. Gibbs v. ADS Alliance Data Systems, Inc., No. 10-2421-JWL, 2011 WL 3205779, at *3

(D. Kan. 2011) (denying employer's motion for summary judgment).

239. Naber v. Dover Healthcare Associates, Inc., 765 F. Supp. 2d 622, 646-47 (D. Del. 2011) (finding issue of fact as to disability but granting employer's motion for summary judgment because employee failed to show that legitimate, non-discriminatory reason for termination was pretextual); Kinney v. Century Serv. Corp. II, No. 1:10-cv-00787-JMS-DML, 2011 WL 3476569 , at *10 (S.D. Ind. 2011) (denying employer's motion for summary judgment).

240. See Rohr v. Salt River Project Agric. Improvement \& Power Dist., 555 F.3d 850, 861-62 (9th Cir. 2009) (finding issue of fact as to disability under ADA and noting that ADAAA "bolstered" this conclusion, and reversing grant of summary judgment to employer).

241. Franchi v. New Hampton School, 656 F. Supp. 2d 252, 258.59 (D.N.H. 2009) (denying school district's motion to dismiss as to claim of disability).

242. Wells v. Cincinnati Children's Hosp. Medical Center, 860 F.Supp.2d 469, $477-478$ (S.D. Ohio 2012) (denying employer's motion for summary judgment).

243. See Beveridge v. HD Supply Waterworks, L.T.D., No. 7:08-CV-52 (HL), 2009 WL 4755370, at *5 n.8 (M.D. Ga. 2009) (stating that “under [ADA's] broadened definition, [an employee with insomnia] would likely be successful in proving he was 'regarded as' disabled" based on his termination four days after falling asleep at work).

244. Markham v. Boeing Company, No.10-1363-MLB, 2011 WL 6217117, at *4-5 \& n.8 (D. Kan. 2011) (finding issue of fact as to disability but granting employer's motion for summary judgment because employee failed to offer sufficient evidence of causation or pretext); Gil v. Vortex, LLC, 697 F. Supp. 2d 234, 239-41 (D. Mass. 2010) (denying employer's motion to dismiss).

245. Lowe v. American Eurocopter, LLC, No. 1:10CV24-A-D, 2010 WL 5232523, at *7-8 (N.D. Miss. 2010) (denying employer's motion to dismiss).

246. Gaus v. Norfolk Southern Railway Co., No. 09-1698, 2011 WL 4527359, at *17 (W.D. Pa. 2011) (denying employer's motion for summary judgment).

247. See Carmona v. Southwest Airlines Co., 604 F.3d 848, 855, 859 (5th Cir. 2010) (stating that amendments to ADA "would be very favorable to [plaintiff's] case if they are applicable, because they make it easier for a plaintiff with an episodic condition [like psoriatic arthritis] . . , to establish that he is an 'individual with a disability"').

248. Medvic v. Compass Sign Co., LLC, No. 10-5222, 2011 WL 3513499, at *7 (E.D. Pa. 2011) (denying employer's motion for summary judgment).

249. See 154 CONG. REC. S8843 (daily ed. Sep. 16, 2008) (Statement of Managers) ("The 
impairments, not just those typically considered to be "disabilities," there is good reason for GID to be within that scope of coverage..$^{250}$

\section{C. “Disability Rights Protection Stigmatizes Transgender People by Legitimating the GID Diagnosis"}

But what about those who do not believe that GID is an impairment at all-would GID's inclusion under the ADA stigmatize transgender people by legitimating the GID diagnosis? This is a harder question. As many commentators have noted, "[b]eing transgender is a quintessentially stigmatic condition. . . ."251 People who do not adhere to gender norms are considered the epitome of "abnormal": neglect, prejudice, and stereotypes are hallmarks of their experience; murder, suicide, homelessness, joblessness, and poverty are tragically common in their community. ${ }^{252}$

The GID diagnosis plays a paradoxical role with regard to stigma. On the one hand, it alleviates suffering by "facilitat[ing] access to medical and technological means for transitioning. ... [I]t makes life livable." 253 But the diagnosis also comes at a price. As Professor Judith Butler writes,

\section{[GID] subscribes to forms of psychological assessment that assume}

that the diagnosed person is affected by forces he or she does not

[ADAAA] . . ensures that the emphasis in questions of disability discrimination is properly on the critical inquiry of whether a qualified person has been discriminated against on the basis of disability, and not unduly focused on the preliminary question of whether a particular person is a 'person with a disability." ); see also Barry, Toward Universalism, supra note 1, at 278.

250. See GLAD, supra note 160, at 6 \& n.4 ("Misunderstandings about the term 'disability,' and the stigma associated with disability, should not prevent people's access to the courts and other protections ... . Rather than restrict the valid legal options of transgender people [under disability law], work must be done to eliminate the stigma associated with disability."); see also Chung, supra note 199, 34 (stating that "applying disability laws to individuals not "traditionally' thought of as disabled," like transgender people, "advances a more dynamic interpretation of disability anti-discrimination statutes").

251. Levi \& Klein, supra note 35 , at 88.

252. According to a 2011 survey of transgender individuals conducted by the National Center for Transgender Equality and the National Gay and Lesbian Task Force, survey respondents were "nearly four times more likely to have a household income of less than $\$ 10,000 /$ year compared to the general population" and experienced unemployment and homelessness at twice the rate of the general population. Also, " $41 \%$ of respondents reported attempting suicide compared to $1.6 \%$ of the general population" and nearly all reported some form of discrimination or harassment - in school and at work, and in housing, healthcare, and public accommodations. INJUSTICE AT EVERY TURN, supra note 18, at 2 . International Transgender Day of Remembrance is held each year on November 20 to memorialize members of the Transgender community who have been murdered. See The Matthew Shepard Hate Crimes Prevention Act: Hearing on S. 909, Before the S. Comm. on Judiciary, 111 th Cong. 1 (2009) (statement of the National Center for Transgender Equality), available at http:/ / transequality.org/PDFs/ S909_NCTE_testimony.pdf ("The transgender community has anecdotally reported on more than one bias motivated murder of a transgender person per month over the past few decades.").

253. Butler, supra note 13 , at $274,285$. 
understand; it assumes that there is delusion or dysphoria in such people; it assumes that certain gender norms have not been properly embodied and that an error and a failure have taken place; it makes assumptions about fathers and mothers, and what normal family life is and should have been; it assumes the language of correction, adaptation, and normalization; it seeks to uphold the gender norms of the world as it is currently constituted and tends to pathologize any effort to produce gender in ways that fail to conform to existing norms. ...254

As a result, the diagnosis "takes on a life of its own, ... mak[ing] life harder for those who suffer by being pathologized and who lose certain rights and liberties, including child custody, employment, and housing, by virtue of the stigma attached to the diagnosis ..." 255 According to Professor Butler, the "pathologizing force" of the GID diagnosis can disable - and even kill-transgender people by "mak[ing] them feel in a stigmatized position and, in some cases, contribut[ing] to a suicidal conclusion." 256 With good reason, many in the transgender community have sought to eliminate GID as a DSM diagnosis altogether, just as the gay community successfully did with homosexuality years ago. ${ }^{257}$

\section{The ADA Already Recognizes GID as an Impairment}

The stigma surrounding a GID diagnosis should not be underestimated, and the stakes are high. ${ }^{258}$ While the GID diagnosis no doubt plays a role in

254. Id. at 275.

255. Id. at 285; see also INJUSTICE AT EVERY TURN, supra note 18, at 197 (noting "perceived stigma attached with [gender-related] mental health diagnoses").

256. Butler, supra note 13, at 276; see also id. 295 ("[O]ne has to ask whether the diagnosis of transgendered youth does not act precisely as peer pressure, as an elevated form of teasing, as a euphemized form of social violence."). For a thoughtful discussion of the promise and problems inherent in the overlap between disability rights and transgender rights, see Dean Spade, Resisting Medicine, Re/Modeling Gender, 18 BERKELEY WOMEN'S L.J. 15, 35 (2003) (“I do not want to make trans rights dependent upon GID diagnoses, because such diagnoses are not accessible to many low income people; because I believe that the diagnostic and treatment processes for GID are regulatory and promote a regime of coercive binary gender; and because I believe that GID is still being misused by some mental health practitioners as a basis for involuntary psychiatric treatment for gender transgressive people. I do not want to legitimize those practices through my reliance on the medical approach to gender nonconformity.").

257. Compare Chung, Identity or Condition?, supra note 199 (discussing transgender community's opposition to GID diagnosis), with KUTCHINS \& KIRK, supra note 3, at 71-72 (explaining history of gay liberation movement's successful efforts to delete homosexuality from DSM in 1974).

258. See Butler, supra note 13, at 276; cf. KUTCHINS \& KIRK, supra note 3, at 77 ("If homosexuality were still considered a mental illness, business and insurance companies would not be offering health coverage for domestic partners, the army would still be using psychiatry to screen suspected homosexuals for discharge, and many of the other advances in gay rights would not be part of our culture."); id. at 61-62 (discussing transformation of homosexuality 
the stigmatization of transgender people, ADA coverage of GID would do nothing to further its legitimacy - at least nothing more than the ADA does at present. Unlike homosexuality and bisexuality, which the ADA states "are not impairments and as such are not disabilities," the ADA states only that GID is not a covered "disability." 259 Implicitly, the ADA therefore already recognizes that GID is an impairment, but refuses to cover GID by stating that it is not a "disability" (only "disabilities" are covered under the ADA - not impairments). 260 The only change made by the ADA Inclusion Act would be to allow GID to be considered a covered "disability."

But this textual argument aside, the risk of stigmatizing transgender people by covering them under the law seems far outweighed by the stigma that attaches to their continued exclusion under the law. While it is possible that GID coverage might stigmatize transgender people by somehow strengthening the "status" of the GID diagnosis, it is more likely that the ADA's exclusion of GID currently stigmatizes transgender people by marking them as undeserving of legal protection. ${ }^{261}$ This is especially true given that Congress did nothing to change the GID exclusion when it expanded the definition of "disability" in 2008.262 Having the law on one's side seems far less stigmatizing than having a law that continues to group GID with pyromania and pedophilia and permits discrimination with impunity. In fact, it is these very prejudices and stereotypes that the ADA is designed to remedy. As Professor Levi notes, "[t]o avoid relying on disability law for protections because of stigma would exacerbate the problem the laws seek to redress." 263

\section{Social Construction is Not a Reason to Deprive Legal Protection}

Another argument against disability rights protection for GID is that GID is a social construction, not an impairment. The problem with this argument is that all impairments - both physical and mental-are, to a certain extent, socially constructed. All impairments are named and diagnosed, and the process of naming and diagnosis are social, and therefore contin-

from something "on which most traditional moral opprobrium rested" to something "good" following removal of homosexuality from DSM, and stating that "[n]o longer was the problem an individual moral struggle to overcome temptation and avoid sin or a psychological struggle to overcome overwhelming desires") (internal quotation marks omitted).

259. 42 U.S.C. $\$ 12211$ (a)-(b) (2006) (emphasis added).

260. Id. $\$ 12211(\mathrm{~b})$.

261. See id.; see also Hiegel, supra note 147, at 1,453 ("By leaving open a space of permissive employer discrimination, the Act identifies the sexual 'deviant' as the new pariah, using the legal machinery of the state to mark as outsiders those whose noncompliant body renders them unfit for full integration into a working community.").

262. See supra section IV.A.1.

263. Jennifer L. Levi, Clothes Don't Make the Man (or Woman), But Gender Might, 15 COlumbia J. Gender \& L. 90, 106 (2006). 
gent, exercises. ${ }^{264}$ Autism, for example, need never have been named and diagnosed. 265 Children exhibiting the subjective behavioral features we now call autism could have been diagnosed with "childhood schizophrenia" or need never have been diagnosed at all.266 These same contingencies apply to GID, which has been named and renamed over the years (from "Transsexualism" in the DSM-III-R to "Gender Identity Disorder" in the DSM-IV to "Gender Dysphoria" in the proposed DSM-5), and which is diagnosed based on subjective behavioral criteria. ${ }^{267}$ The fact that impairments are socially constructed, by itself, does not justify withholding legal protection.

"No," some might further argue, "autism is 'real,' while GID is not." What they mean is that GID does not refer to some objectively-measurable biological pathology and, therefore, it is not an impairment but rather the pathologizing of a perfectly healthy way of being. ${ }^{268}$ According to this reasoning, however, autism (and many other mental impairments) is not an "impairment" either. While the discovery of some biological pathology underlying autism appears likely, there is none yet. ${ }^{269}$ And there are plenty of autistic people (i.e., the neurodiversity movement) who, like many in the transgender community, resist the pathologizing of autism and instead recast autism as a different way of thinking and being that should not be cured or normalized. ${ }^{270}$ Given that both autism and GID lack an objectively-measurable pathology, and given that many members of both communities regard these "impairments" as different ways of being, why should the law treat them differently?

"Okay, then," one might further argue, "the ADA should exclude both autism and GID because neither is an impairment." Rather than amending the ADA to treat GID and autism as protected impairments, the argument goes, the ADA ought to be amended to treat GID and autism the same as homosexuality and bisexuality, that is, as not impairments at all.271 But this argument also misses its mark. Autism and GID do not cease being impairments because many of those classified as having these conditions do

264. See Barry, Gray Matters, supra note 162, at 204-05.

265. See id. at 209.

266. See id.

267. See Gender Dysphoria, DSM-5 Proposed Revision, supra note 3; DSM-IV, supra note 34, at 532-38; DSM-III-R, supra note 34 , at 74-76.

268. Cf. Butler, supra note 13, at 275 ("[T] he diagnosis [of GID] is adamantly opposed because it continues to pathologize as a mental disorder what ought to be understood instead as one among many human possibilities of determining one's gender for oneself.").

269. See Barry, Gray Matters, supra note 162, at 168, 173-74.

270. See id. at 186-89; see also Malloy, supra note 147, at 301 ("Some [transgender] activists contend that th[e disability] categorization is demeaning and stereotypical because it implies that transsexual individuals are not normal. In this regard, the transsexual community is not alone; individuals in existing disabled groups, such as paraplegics and the deaf, are also resistant to being characterized as such.") (citation omitted).

271. See 42 U.S.C. 12211(a) (2006). 
not consider them to be impairments. The medical establishment, of course, continues to believe that autism and GID are impairments ${ }^{272}$ but, more importantly, so do many of those diagnosed. The lived experiences of those classified as having these conditions are not universal. While the neurodiverse may resist the pathologizing of autism, forego medical "treatment" such as Applied Behavioral Analysis, and advocate against "cures," many parents of autistic children may do just the opposite. ${ }^{273}$ Likewise, while many transgender people resist the GID diagnosis and forego hormonal treatment and surgery to align their anatomy with their gender identity, many others seek out the diagnosis and treatment for it. ${ }^{274}$ Rejecting the GID diagnosis is therefore not a principled reason for withholding legal protection for GID - it merely favors one side's experience over another's.

\section{D. "Disability Rights Protection Would be Underinclusive"}

Another argument against disability rights protection for GID is that it is bound to be under-inclusive. The ADA Inclusion Act would most likely cover a person diagnosed with GID whose distress substantially limits the person's brain function or ability to sleep, eat, or concentrate, whose lifelong medical treatment (or attendant side effects) substantially limits the person's ability to "car[e] for oneself," or whose genital surgery substantially limits "the operation of . . reproductive functions." 275 But, one might argue, it probably would not cover transgender people who do not have the diagnosis because they do not want it, ${ }^{276}$ because they do not meet the diagnostic criteria, or because they lack access to the medical system that provides such a diagnosis. ${ }^{277}$

This argument fails to account for recent changes to the law. As discussed above, the 2008 amendments make clear that the ADA covers nearly anyone who is "disabled" (i.e., adversely treated) based on an impairment,

272. Autism Spectrum Disorder, DSM-5 Proposed Revision, supra note 3.

273. See Barry, Gray Matters, supra note 162, at 171-72, 186.

274. See Butler, supra note 13 , at 274-75.

275. See 42 U.S.C. $\$ 12102(2)(A)(2006)$ ("[M]ajor life activities include, but are not limited to, caring for oneself, eating, sleeping . . concentrating . . . "); id. § 12102(2)(B) ("[A] major life activity also includes the operation of a major bodily function, including but not limited to ... reproductive functions.").

276. See Butler, supra note 13 , at 275.

277. See Franklin H. Romeo, Beyond a Medical Model: Advocating for a New Conception of Gender Identity in the Law, 36 ColuM. HuM. RTS. L. REV. 713, 730 (2005) (stating that "[1]ow-income transgender people who are unable to afford trans-friendly healthcare . . . are unlikely to be able to avail themselves of legal protections that have emerged" from courts' reliance on diagnosis of GID); see also About Us, THE JIM COLLINS FOUNDATION, http:/ jimcollinsfoundation. org/?page_id=34 (last visited Dec. 11, 2012) (dedicated to "rais[ing] money to fund genderconfirming surgeries for those transgender people who need surgery to live a healthy life, but have no ability to pay for it themselves"). 
whether that impairment is real or perceived, limiting or not. ${ }^{278} \mathrm{~A}$ transgender man who does not seek out a GID diagnosis or otherwise avail himself of medical interventions (and would not qualify for a GID diagnosis even if he did), and who is not functionally limited in any way, but who dresses in traditionally male clothing and is discriminated against as a result, is most likely "regarded as" having GID.279 The ADA Inclusion Act would most likely cover him. ${ }^{280}$

As other commentators have noted, this argument also ignores "a truism of a limitation of disability antidiscrimination laws generally," which is that not all people will be found "disabled." 281 While the 2008 amendments drastically lower the bar for legal protection, this truism remains. "This is not a reason, however, to forego pursuing critical nondiscrimination protections for those transgender people who can meet the definition of disability." 282 Consider autism's vast spectrum, where some autistic people are profoundly limited in their life functioning (e.g., self-care, speaking), and others are not. ${ }^{283}$ Consider also the neurodiversity movement's outer rim, the so-called "autistic cousins" (i.e., non-autistic people with significant social and communication abnormalities that render them significantly "autistic-like"). ${ }^{284}$ While "cousins," and even some high-functioning autistic people, will inevitably be denied accommodations under the amended ADA, 285 the neurodiversity movement does not - and should not-suggest that autism should not be protected under the law. The same reasoning arguably applies to the transgender community and GID.

\section{CONCLUSION}

When the ADA was signed into law in 1990, President George H.W.

278. See 42 U.S.C. $\$ 12102(3)$ (A) (2009).

279. See id.

280. Unlike a person with GID who is substantially limited in a major life activity, a person "regarded as" having GID would not be entitled to a reasonable accommodation. 42 U.S.C. $\$$ 12201(h) (2006).

281. Levi \& Klein, supra note 35 , at 87.

282. 1 d.

283. See supra note 162 and accompanying text; $c f$. SIMON BARON-COHEN, supra note 169 , at $163-64$.

284. See Jim Sinclair, Autism Network International: The Development of a Community and its Culture, AUTISM NETWORK INTERNATIONAL (Jan. 2005), http:/ / www.autreat.com/History of_ANI.html. Mirroring the breadth of the neurodiversity and transgender communities, the Deaf community includes those without hearing impairments. See Harlan Lane, Constructions of Deafness, 10 DiSABILITY \& SOC'Y 171, 179 (1995) ("The claim that one is in the DEAF-WORLD, or that someone else is, is not a claim about hearing status at all. ... All degrees of hearing can be found among Deaf people ... and most people who are hearing-impaired are not members of the DEAF-WORLD.").

285. See Daniela Caruso, Autism in the U.S.: Social Movement and Legal Change, 36 AM. J.L. \& MED. 483, 512-13 (2010) (citing instances where courts denied relief to Autistic plaintiffs under the (unamended) ADA). 
Bush announced that the law would "take[] a sledgehammer to . . the shameful wall of exclusion" separating people with various impairments from "the rich mosaic of the American mainstream." 286 Importantly, the ADA did not remove that wall for everyone. On the eve of passage in the Senate, the ADA's sponsors struck a fateful bargain with several senators, which maintained the wall for people with GID, pedophilia, pyromania, kleptomania, and several other mental impairments considered "immoral, improper, or illegal." 287 From its inception, the ADA was a moral code that excluded from protection those impairments considered morally harmful.

In the years that followed, members of the transgender community coalesced into a formidable political and social movement demanding access to America's mainstream. Their advocacy has done much to raise the profile - and morality - of gender nonconformance. The shameful wall excluding transgender people is falling. Transgender is finally becoming "good."

While legal protections have played an important role in this development, federal disability law is a notable exception. When Congress decided to expand the definition of "disability" in 2008 to include nearly everyone, rendering the ADA "disabilityqueer," Congress deliberately chose not to revisit the GID exclusion. Far from removing the wall of exclusion for transgender people, the 2008 amendments reinforced it. Legal advancements outside of disability law, including a resounding victory before the EEOC in April 2012, have burst holes in the wall. Yet the ADA's GID exclusion still stands - a monument to moral opposition toward gender nonconformity, a bulwark against true transgender equality.

Reasonable arguments against federal disability protection for GID can surely be made. One might argue, for example, that disability protection is not needed or is under-inclusive, or that disability protection is itself stigmatizing. But none of these arguments squarely rebut the moral opposition underlying GID's exclusion from the ADA, nor do they adequately account for the 2008 amendments' expansion of what it means to be "disabled." An "ADA Inclusion Act" would advance transgender policy by removing gender nonconforming people from the ranks of the morally dangerous and providing them with the same protection as nearly everyone else who is discriminated against based on impairment.

The shameful wall of exclusion for transgender people will fall, and true equality for transgender people will come, when the moral case against transgender equality is exposed for what it is - a failure of empathy. Removal of the ADA's GID exclusion, a prominent piece of that wall, ought to be part of the project of making transgender "good."

286. George H.W. Bush, Remarks at the Signing of the Americans with Disabilities Act (July 26, 1990), available at http://www.eeoc.gov/eeoc/history/35th/videos/ada_signing_text .html.

287. See 135 CONG. REC. S10796 supra note 57 and accompanying text (statement of Sen. Warren Rudman). 